\title{
Assessment of the APCC coupled MME suite in predicting the distinctive climate impacts of two flavors of ENSO during boreal winter
}

\author{
Hye-In Jeong • Doo Young Lee $\cdot$ Karumuri Ashok • Joong-Bae Ahn • \\ June-Yi Lee $\cdot$ Jing-Jia Luo $\cdot$ Jae-Kyung E. Schemm $\cdot$ Harry H. Hendon • \\ Karl Braganza $\cdot$ Yoo-Geun Ham
}

Received: 18 March 2011/Accepted: 26 March 2012/Published online: 20 April 2012

(C) Springer-Verlag 2012

\begin{abstract}
Forecast skill of the APEC Climate Center (APCC) Multi-Model Ensemble (MME) seasonal forecast system in predicting two main types of El Niño-Southern Oscillation (ENSO), namely canonical (or cold tongue) and Modoki ENSO, and their regional climate impacts is assessed for boreal winter. The APCC MME is constructed by simple composite of ensemble forecasts from five independent coupled ocean-atmosphere climate models. Based on a hindcast set targeting boreal winter prediction for the period 1982-2004, we show that the MME can predict and discern the important differences in the patterns of tropical Pacific sea surface temperature anomaly between the canonical and Modoki ENSO one and four month ahead. Importantly, the four month lead MME beats the persistent forecast. The MME reasonably predicts the distinct impacts of the canonical ENSO, including the strong winter monsoon rainfall over East
\end{abstract}

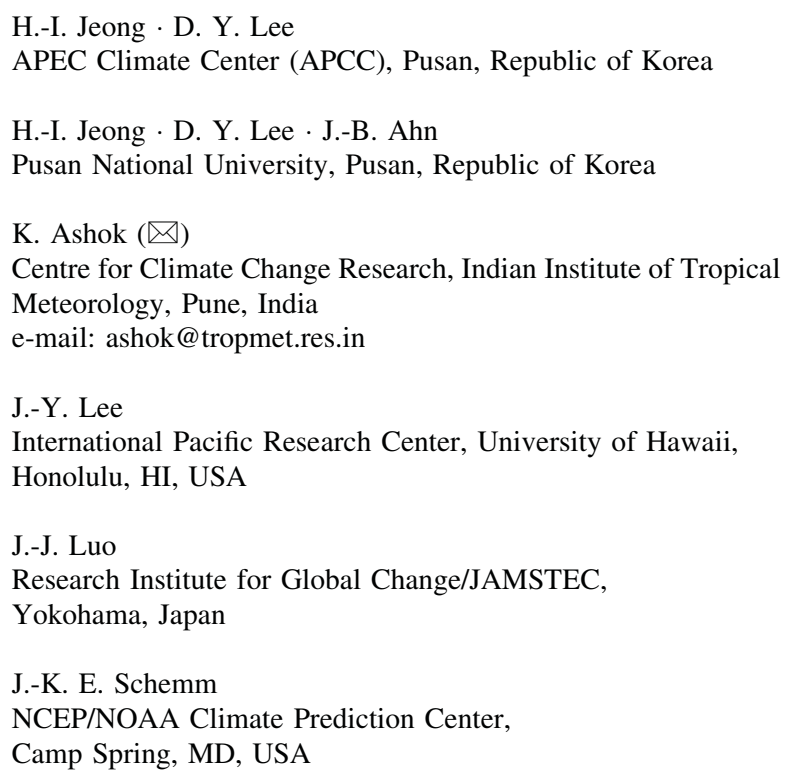

Asia, the below normal rainfall and above normal temperature over Australia, the anomalously wet conditions across the south and cold conditions over the whole area of USA, and the anomalously dry conditions over South America. However, there are some limitations in capturing its regional impacts, especially, over Australasia and tropical South America at a lead time of one and four months. Nonetheless, forecast skills for rainfall and temperature over East Asia and North America during ENSO Modoki are comparable to or slightly higher than those during canonical ENSO events.

Keywords El Niño-Southern Oscillation (ENSO) · Canonical ENSO - ENSO Modoki - Seasonal prediction skill · Teleconnection - Multi-model ensemble (MME) . Coupled general circulation model

H. H. Hendon - K. Braganza

Centre for Australian Weather and Climate Research, Bureau of Meteorology, Melbourne, VIC, Australia

Y.-G. Ham

Global Modeling and Assimilation Office, NASA Goddard Space Flight Center (NASA/GSFC), Greenbelt, MD, USA

Y.-G. Ham

Goddard Earth Sciences Technology and Research Studies and Investigations, Universities Space Research Association, Greenbelt, MD, USA 


\section{Introduction}

There has been considerable amount of research into a new type of ENSO. It has been equivalently referred to as dateline (Larkin and Harrison 2005b), El Niño Modoki (Ashok et al. 2007), Central-Pacific (Yu and Kao 2007; Kao and Yu 2009), and Warm Pool El Niño (Kug et al. 2009, 2010), in order to differentiate it from the typical El Niño that develops further east in the cold tongue of the equatorial Pacific, such as that during 1997 (McPhaden 1999) ${ }^{1}$. A key distinction of El Niño Modoki is that the maximum sea surface temperature anomaly (SSTA) occurs in the central equatorial Pacific rather than in the eastern Pacific and the SSTA is typically flanked by cold anomalies further east and west and lasts for several seasons. El Niño Modoki appears to be a recent phenomenon, with eight El Niño Modoki events having occurred ${ }^{2}$ since 1980s including the recent El Niño Modoki event in 2009 (Ashok et al. 2007; Ratnam et al. 2010). For reference, five ${ }^{3}$ canonical El Niño events, also known as cold tongue El Niño (Hendon et al. 2009) or eastern Pacific El Niño (Yu and Kao 2007) have occurred since 1980. Prior to the 1980's no El Niño Modokis have been reported, though Donguy and Dessier (1983) and Fu et al (1986) discuss distinct characteristics of a few individual events. Anomalous warming in the central Pacific in the pre-1980s period stemmed from transient evolution of canonical El Niño events (e.g., Trenberth and Stepaniak 2001). Studies hint that this recent frequent occurrence of El Niño Modoki is associated with recent climate change in the Pacific, especially the flattening of the tropical Pacific thermocline in association with slackened trade easterlies (Ashok et al. 2007; Turner et al. 2007; Yeh et al. 2009). A flatter thermocline favors generation of SST anomalies in the central Pacific via zonal advection and surface heat flux variations as opposed to SST anomalies further east in the cold tongue that result from vertical displacement of the thermocline as typically occurs in canonical El Niños (Kug et al. 2009; Yu and Kim 2010).

The climatic impacts of Modoki and canonical El Niños, are also distinctly different, especially over East Asia, Australia, and United States (e.g. Larkin and Harrison 2005a; Ashok et al. 2007, 2009a, b; Weng et al. 2007, 2009; Wang and Hendon 2007; Lim et al. 2009; Taschetto and England 2009; Trenberth and Smith 2009; Cai and Cowan 2009; Mo 2010; Pradhan et al. 2011). For example,

\footnotetext{
${ }^{1}$ Rasmusson and Carpenter (1982) mostly discussed westward propagating conventional El Niños which occurred before the 1980s. McPhaden (1999) has catalogued the post-1980s canonical El Niño events such as in 1982/1983 and 1997/1998. The distinction of the post-1980s is that they propagate eastward.

2 1986, 1990, 1991, 1992, 1994, 2002, 2004, and 2009.

3 1982-1983, 1987-1988, 1997-1998, 2006-2007, and 2010.
}

during boreal winter, El Niño Modoki events weaken the East Asian winter monsoon by shifting the low-level anticyclone to the South China Sea, whereas during canonical El Niño the winter monsoon strengthens because the anticyclones shift to the Philippines Seas (Weng et al. 2009). Australian spring rainfall has greatest sensitivity to the SST variations on the eastern edge of the Pacific warm pool area (Wang and Hendon 2007) and it is thus more sensitive to El Niño Modoki events than a canonical El Niño (Hendon et al. 2009; Lim et al. 2009). By contrast, Australian autumn rainfall is sensitive to La Nina Modoki (Cai and Cowan 2009).

Although distinctive impacts of El Niño Modoki events have been well established, there has been little effort to assess the skills of the models in predicting them. Hendon et al (2009) and Lim et al. (2009) showed some limited success in predicting differences between Modoki and canonical El Niños using the Bureau of Meteorology POAMA coupled seasonal forecast model; the prediction skill were limited by systematic model error, whereby the POAMA model is unable to maintain the distinction between Modoki and cold tongue events beyond about 1 season lead time. The present study aims to assess the ability to predict distinctions between Modoki and canonical El Niños using a multi-model approach, whereby systematic model errors might be averaged out. We use the coupled climate prediction Multi-Model Ensemble (MME) suite of the APEC Climate Center (APCC), Korea, and assess its ability to predict the two El Niño phenomena and their distinctive regional impacts. Here we focus on four-month lead (August 1 initial condition) and one-month lead (November 1 initial condition) prediction skill for the boreal winter season, using hindcast for the period 1982-2004.

The next section gives a brief description of the forecast data and MME methodology. In Sect. 3, we examine the ability of the MME to distinguish and predict the two different types of ENSO events and assess the maximum lead time of the MME in predicting the distinction between the ENSO and ENSO Modoki. In Sect. 4, we report prediction skill of regional impacts of two types of ENSO in the Asia-Pacific. The final section comprises of summary and discussion.

\section{Models and evaluation methods}

\subsection{The APCC coupled MME system}

Seasonal climate hindcasts from 5 coupled models from the National Centers for Environmental Prediction (NCEP), the Bureau of Meteorology (BoM), Frontier Research Center for Global Change (FRCGC), Seoul National University (SNU), and APCC are used in this study. A brief 
Table 1 Description of APCC one-tier prediction models

\begin{tabular}{|c|c|c|c|c|}
\hline $\begin{array}{l}\text { Institute } \\
\text { (model name) }\end{array}$ & $\begin{array}{l}\text { AGCM } \\
\text { (resolution) }\end{array}$ & $\begin{array}{l}\text { OGCM } \\
\text { (resolution) }\end{array}$ & $\begin{array}{l}\text { Ensemble } \\
\text { member }\end{array}$ & References \\
\hline $\begin{array}{l}\text { APCC } \\
\text { (APCC-CCSM3) }\end{array}$ & $\begin{array}{l}\text { CAM3 } \\
\text { (T85L26) }\end{array}$ & $\begin{array}{l}\text { POP1.3 } \\
(\mathrm{gx} 1 \mathrm{v} 3 \mathrm{~L} 40)\end{array}$ & 5 & Jeong et al. (2008) \\
\hline $\begin{array}{l}\text { BoM } \\
\text { (POAMA) }\end{array}$ & $\begin{array}{l}\text { BAMv3.0d } \\
(\mathrm{T} 47 \mathrm{~L} 17)\end{array}$ & $\begin{array}{l}\text { ACOM2 } \\
\left(0.5^{\circ}-1.5^{\circ} \text { lat } \times 2^{\circ} \text { lon } \mathrm{L} 25\right)\end{array}$ & 10 & Zhao and Hendon (2009) \\
\hline $\begin{array}{l}\text { FRCGC } \\
\text { (SINTEX-F) }\end{array}$ & $\begin{array}{l}\text { ECHAM4 } \\
\text { (T106L19) }\end{array}$ & $\begin{array}{l}\text { OPA8.2 } \\
\left(2^{\circ} \cos (\text { lat }) \times 2^{\circ} \text { lon L31 }\right)\end{array}$ & 9 & Luo et al. (2005) \\
\hline $\begin{array}{l}\text { NCEP } \\
(\text { NCEP_CFS) }\end{array}$ & $\begin{array}{l}\text { GFS } \\
\text { (T62L64) }\end{array}$ & $\begin{array}{l}\text { MOM3 } \\
\left(1 / 3^{\circ} \text { lat } \times 1^{\circ} \text { lon } \mathrm{L} 40\right)\end{array}$ & 15 & Saha et al. (2006) \\
\hline $\begin{array}{l}\mathrm{SNU} \\
(\mathrm{SNU})\end{array}$ & $\begin{array}{l}\text { SNU } \\
(\mathrm{T} 42 \mathrm{~L} 21)\end{array}$ & $\begin{array}{l}\text { MOM2.2 } \\
\left(1 / 3^{\circ} \text { lat } \times 1^{\circ} \text { lon L32 }\right)\end{array}$ & 6 & Ham and Kang (2010) \\
\hline
\end{tabular}

description of the models is provided in Table 1. The NCEP_CFS and the POAMA model data are from the operational hindcasts of the NCEP in USA and the BoM in Australia respectively, while the SINTEX-F from FRCGC in Japan and SNU model data have been obtained through the CliPAS $^{4}$ project (Wang et al. 2009; Ham and Kang 2010; Lee et al. 2010). The APCC model is based on the UCAR CCSM3 (Collins et al. 2006; Kiehl et al. 2006; Meehl et al. 2006) and has been developed as a seasonal prediction system at the APCC (Jeong et al. 2008).

In this study, we form the multi-model ensemble using the simple composite method. In this technique, equal weights are assigned to the ensemble mean predictions of each model with the assumption that each model is independent. The mean bias from each model is removed by forming anomalies with respect to the each model's own seasonal climatology. In this study, we focus on the boreal winter (December through February; DJF) for the period 1982-2004. We use the hindcasts of the 5 selected models for DJF with the initial conditions representing 1 November (one-month lead seasonal prediction), and similar hindcasts but with initial conditions of 1 August (fourmonth lead seasonal prediction).

The observed and reanalyzed datasets used for the hindcast verification are the Global Precipitation Climatology Project (GPCP) data (Adler et al. 2003), the National Centers for Environmental Prediction (NCEP)Department of Energy (DOE) reanalysis 2 data (Kanamitsu et al. 2002) for atmospheric variables, and the NOAA Optimum Interpolation Sea Surface Temperature (OISST) data (Reynolds et al. 2002), all for the period of 1982-2004.

\subsection{Evaluation methods}

We first carry out an Empirical Orthogonal Function (EOF) analysis to identify the observed dominant spatial patterns

\footnotetext{
${ }^{4}$ http://iprc.soest.hawaii.edu/ jylee/.
}

of SST anomalies in the tropical Pacific. We then extract the teleconnection patterns using a linear regression analysis of the observed circulation, rainfall and temperatures on the principal components of the top two EOF modes, which represent the canonical and Modoki ENSO, respectively (Ashok et al. 2007). In order to examine the skill in predicting these observed features, we carry out similar analyses on the hindcasts from the MME. Further, pattern correlation and composite analysis methods are employed to investigate the relationship between observations and coupled MME predictions for SST, rainfall, and temperature in various regions surrounding the Pacific.

\section{Hindcast skills for two types of ENSO}

\subsection{Prediction of the leading EOF modes of DJF SST}

The first two leading EOF modes of the observed DJF SSTA over the tropical Pacific region $\left(30^{\circ} \mathrm{S}-30^{\circ} \mathrm{N}, 120^{\circ} \mathrm{E}-\right.$ $60^{\circ} \mathrm{W}$ ) are presented in Fig. 1a, b. The spatial pattern of the first EOF mode (EOF1) captures the well-known canonical ENSO pattern with SSTA having the same sign throughout the equatorial eastern Pacific and with maximum occurring at about $155^{\circ} \mathrm{W}-115^{\circ} \mathrm{W}$ (Fig. 1a). The correlation coefficient between the observed first principal component (PC1) and Niño3 SST index is $0.98^{5}$. This EOF1 explains about $55 \%$ of tropical Pacific SST variance for the period of 1982-2004. The second mode (EOF2), which explains $11.5 \%$ of the variance, has maximum near the dateline and is flanked by opposite signed anomalies in the far eastern and far western Pacific (Fig. 1b). The EOF2 has been associated with ENSO Modoki (Ashok et al. 2007; Hendon et al. 2009). The correlation coefficient between the

\footnotetext{
5 The area-averaged sea surface temperature anomaly over the region bounded by $\left(5^{\circ} \mathrm{S}-5^{\circ} \mathrm{N}, 150^{\circ} \mathrm{W}-90^{\circ} \mathrm{W}\right)$ is known as Niño3 index, which is a well-known ENSO index.
} 

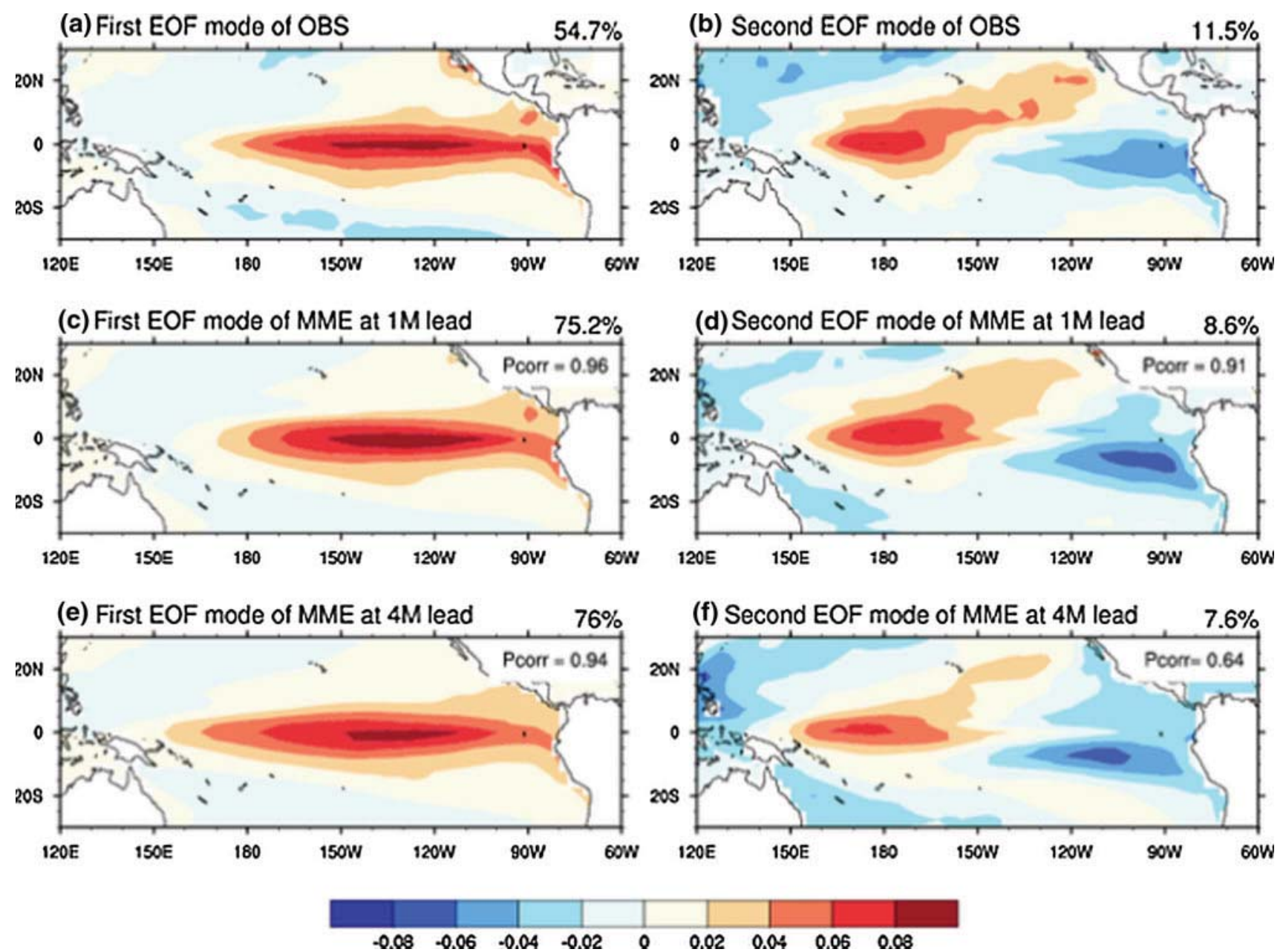

Fig. 1 First two modes of spatial patterns of EOFs for $(\mathbf{a}, \mathbf{b})$ observed sea surface temperature anomalies over the tropical Pacific $\left(30^{\circ} \mathrm{S}-\right.$ $30^{\circ} \mathrm{N}, 120^{\circ} \mathrm{E}-60^{\circ} \mathrm{W}$ ) during the period of $1982-2004$. c and $\mathbf{d}$ Same as $\mathbf{a}$ and $\mathbf{b}$, except for the MME predicted sea surface temperature

observed second principal component (PC2) and the El Niño Modoki index is $0.86^{6}$.

The ability of the MME to capture the distinctive spatial patterns of these two types of ENSO is assessed by performing a similar EOF analysis on the MME hindcasts at 1and 4-month lead time, respectively. At 1-month lead time, the MME well captures the spatial patterns of the first two leading EOF modes with high fidelity (Fig. 1c, d). The spatial pattern correlation between the observed and predicted eigenvectors is 0.96 for the EOF1 and 0.91 for the EOF2. However, the variance explained by the EOF1 for MME is $75.2 \%$, indicating that the MME prediction

${ }^{6}$ The El Niño Modoki index or EMI is defined as EMI = $[\mathrm{SSTA}]_{\mathrm{C}}-0.5[\mathrm{SSTA}]_{\mathrm{E}}-0.5[\mathrm{SSTA}]_{\mathrm{W}}$, where the square bracket with a subscript represents the area-mean SSTA, averaged over one of the three regions specified as the central $\left(\mathrm{C}: 165^{\circ} \mathrm{E}-140^{\circ} \mathrm{W}, 10^{\circ} \mathrm{S}-\right.$ $10^{\circ} \mathrm{N}$ ), eastern $\left(\mathrm{E}: 110^{\circ} \mathrm{W}-70^{\circ} \mathrm{W}, 15^{\circ} \mathrm{S}-5^{\circ} \mathrm{N}\right)$, and western $(\mathrm{W}$ : $\left.125^{\circ} \mathrm{E}-145^{\circ} \mathrm{E}, 10^{\circ} \mathrm{S}-20^{\circ} \mathrm{N}\right)$. anomalies at 1-month lead time. Pattern correlations between the observed and MME predicted spatial patterns of each EOF mode are also given. $\mathbf{e}$ and $\mathbf{f}$ Same as $\mathbf{c}$ and $\mathbf{d}$ respectively, but at 4-month lead time

explains a significantly larger amount of the variance than the observed counterpart. The variance explained by the EOF2 from the MME is $8.6 \%$, indicating that the MME does not adequately capture the observed Modoki ENSO variance, despite being able to reproduce its spatial pattern reasonably well.

The time series of the corresponding normalized PC1 and $\mathrm{PC} 2$ for 1- and 4-month lead time are presented in Fig. 2. The PC1 (PC2) from observations is well correlated at $0.94(0.86)$ with that from MME hindcasts at 1-month lead. These correlations are statistically significant at $99 \%$ confidence level from two-tailed Student's $t$ test. It can be discerned that the MME well predicts both the spatial structure and temporal behavior of these leading two EOFs of SST. Because EOF1 is associated with canonical ENSO (e.g. correlation of observed PC1 with Nino3 SST index is 0.98 ) and EOF2 is associated with ENSO Modoki (correlation of observed PC2 with the El Niño Modoki index is 
Fig. 2 Principal component (PCs) time series of the first two EOF modes of sea surface temperature anomalies over the tropical Pacific $\left(30^{\circ} \mathrm{S}-30^{\circ} \mathrm{N}\right.$, $120^{\circ} \mathrm{E}-60^{\circ} \mathrm{W}$ ) during the period of 1982-2004 from the observations (black), from 1-month lead time MME predictions $(\mathrm{red})$ and from 4-month lead time MME predictions (blue). Time series are normalized by their respective $\mathrm{SD}$ (a) Normalized time series of PC1

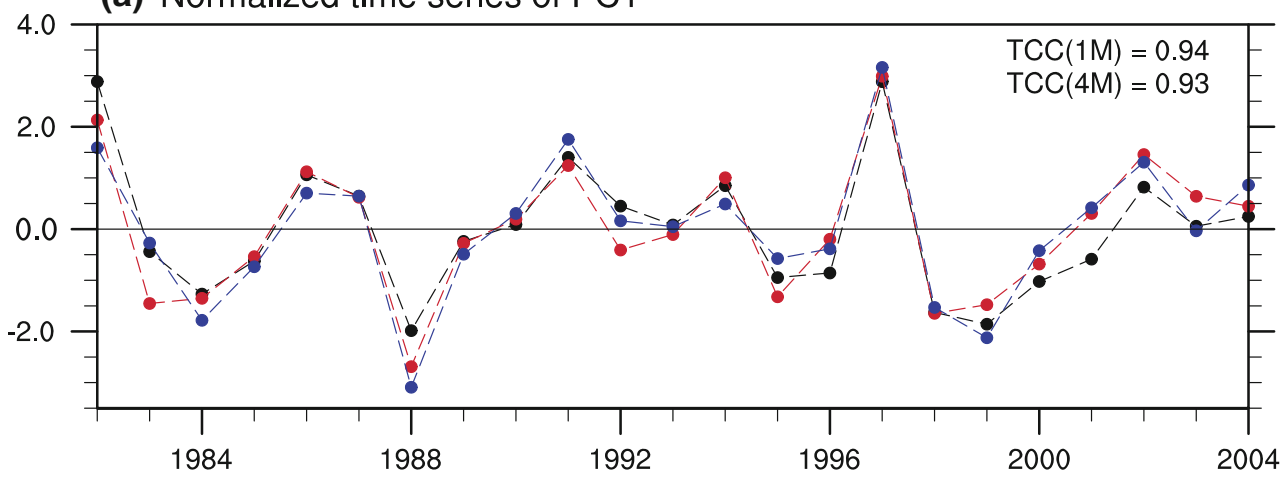

(b) Normalized time series of PC2

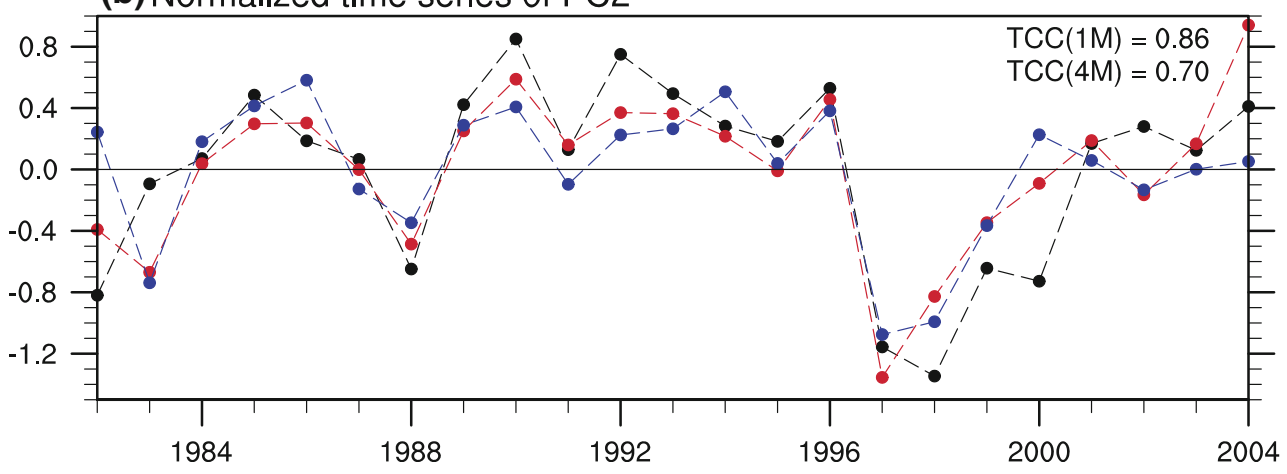

0.86), we can infer that the MME is able to predict the important differences in SSTA between cold tongue and ENSO Modoki events, at least at 1-month lead time.

At 4-month lead, the MME is seen to more or less retain the high fidelity in capturing the spatial pattern of the EOF1 (Fig. 1e). The spatial pattern correlation between the observed and predicted eigenvectors is 0.94 , slightly less than the corresponding value at 1 -month lead. The spatial pattern of the EOF2 at 4-month lead (Fig. 1f) indicates a weakened central tropical Pacific loading which shifts by about $15^{\circ}$ to the west as compared to its position at 1-month lead. We also see an intensified eastern Pacific loading. The variance explained by the EOF2 from the $\mathrm{MME}$, and the pattern correlation with the corresponding EOF2 from observations, have further reduced to $7.6 \%$ and 0.64 respectively, indicating that the ability of the MME deteriorates further in capturing the Modoki associated variance and SSTA pattern at a 4-month lead. The PC1 (PC2) from observations is correlated at $0.93(0.7)$ with that from MME hindcasts at 4-month lead time (Fig. 2). Even at 4-month lead time, the correlations are statistically significant at $99 \%$ confidence level from twotailed Student's $t$ test.

Also, we have examined the performance of individual models for the dominant spatial patterns and temporal behavior of the first two leading EOF modes of the SSTAs at 1- and 4-month lead time in Fig. 3, and compared with those of MME prediction. Though the prediction skills of some individual models show a slightly higher than those of MME, it can be seen that, on the whole, the skills of MMEs, such as the spatial (temporal) correlations of EOF2 pattern (PC2 time series) of SST anomalies at 1-month lead, are superior to those of the individual models as well as the mean skills of individual models.

\subsection{Prediction of the two major types of ENSO}

Wang et al. (2009) demonstrated that seven coupled models' MME is capable of predicting the eastern-Pacific (EP) type ENSO with a high fidelity for the 21 years of 1981-2001 and its anomaly correlation skill for monthly Nino 3.4 SST index reaches 0.77 and 0.81 at a 6-month lead with May 1st and November 1st initial condition, respectively. In this study, we examine the feasibility for the APCC Coupled MME in predicting the two types of ENSO at a four-month lead for DJF mean (four-month for December mean and six-month lead for February mean). Figure 4 presents time series of DJF Niño3 and EMI from observations and one- and four-month lead MME prediction. The coupled MME well predicts both indices even at four-month lead with a high fidelity but better-captures Niño3 index than EMI, particularly at long lead. The temporal correlation coefficient for DJF Niño3 (EMI) between observation and MME prediction is $0.94(0.91)$ 
Fig. 3 Distribution of the performances of the MME, individual models against the first two observed EOF modes of SSTAs over the tropical Pacific $\left(30^{\circ} \mathrm{S}-30^{\circ} \mathrm{N}, 120^{\circ} \mathrm{E}-\right.$ $60^{\circ} \mathrm{W}$ ) during the period of 1982-2004. The left panel is for the pattern correlation coefficients of the eigenvector, and the right panel is for the temporal correlation coefficients of the corresponding principal component. The skills for 1-month (4-month) lead are denoted with red (blue) (a) The PCC of Eigenvector

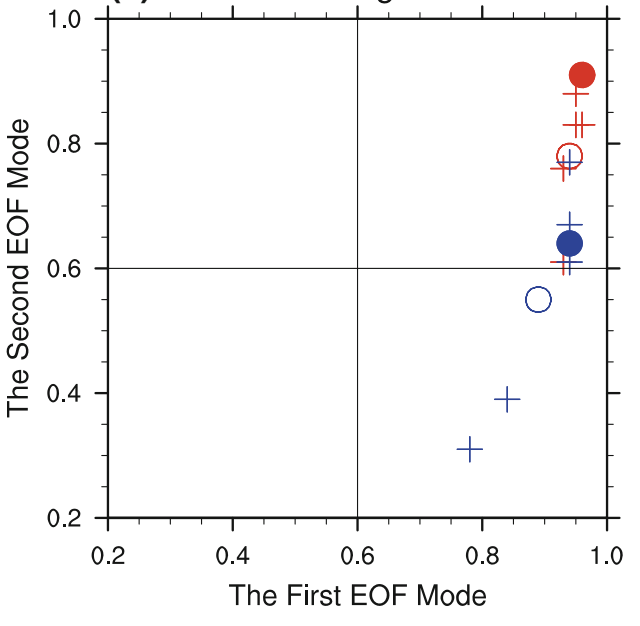

MME + Each Model (b) The TCC of PC Time Series

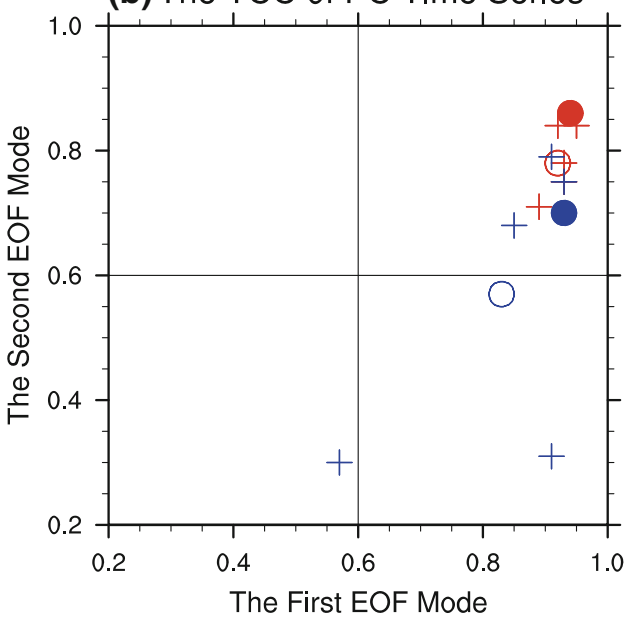

O Mean of Models

Fig. 4 Time series of seasonal mean anomalies of a Niño3 and b EMI indices from observations (black) and the MME predictions at 1 (red) and 4 (blue) month lead time. Temporal correlations between the observed and MME predicted time series are also given at the upper right. Anomalies are normalized by the SD of their indices

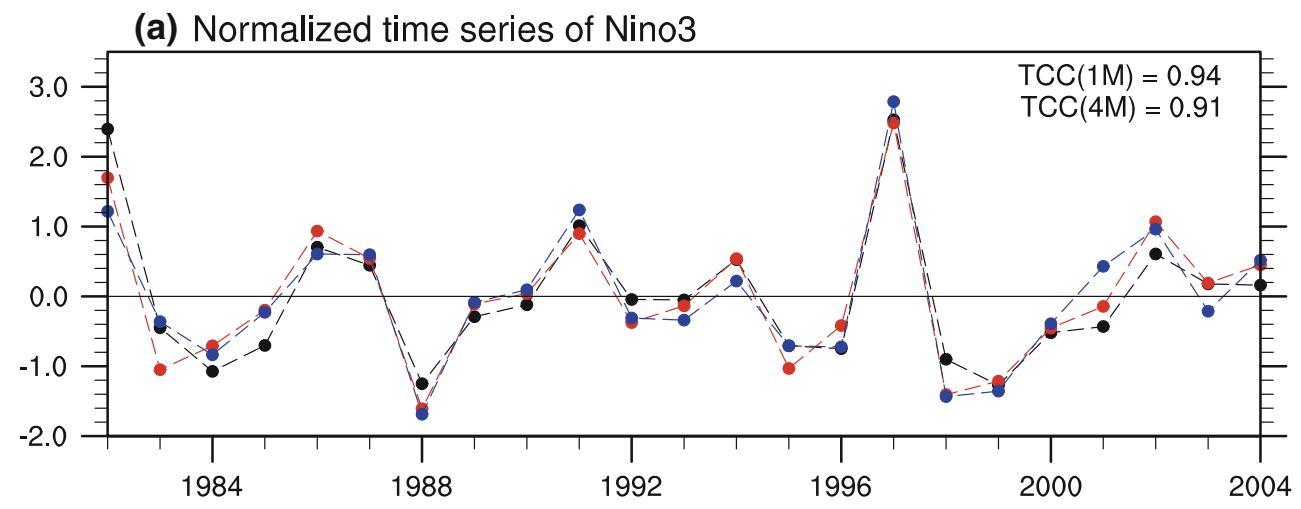

(b) Normalized time series of EMI

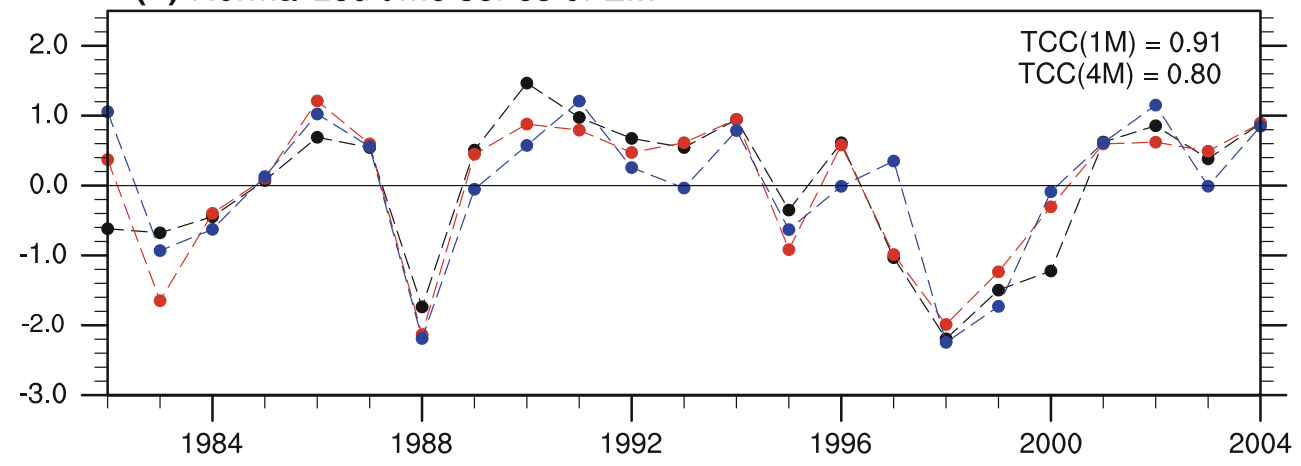

and $0.91(0.80)$ for one- and four-month lead prediction, respectively. Interestingly, while the 1-month lead skills fall slightly below the persistence skill of 0.97 (0.94) for DJF Niño3 (EMI) at 1-month lead, the MME skills are higher than the corresponding persistence skill of 0.81 (0.79) for 4-month lead. The results are similar to that reported for a few models in a recent study (Jin et al. 2008).

Since it is important for models to also distinctively capture the distribution of SST anomalies over the Tropical Pacific associated with canonical El Niño and Modoki El
Niño (Hendon et al. 2009), composite analysis is applied using strong events of the two types of El Niño; following Weng et al. (2009), we choose the three strongest El Niños (1982-1983, 1987-1988 and 1997-1998) and the three strongest El Niño Modoki events (1994-1995, 2002-2003 and 2004-2005) during the study period. Larger amplitude of the SSTA in the eastern Pacific for the El Niño events and smaller amplitude in the eastern Pacific for the El Niño Modoki events are seen (Fig. 5) to be maintained in the forecasts up to a lead time of 4 months. Pattern correlation 
quantifies the distinction (Hendon et al. 2009). The pattern correlation $(\mathrm{r}=0.52)$ between the observed composited anomalies for the two types of El Niño shown in Fig. 5a, b is significant, but yet modest reflecting that about $75 \%$ of individual variances of the two types of events are, to a large extent, dissimilar. In comparison, the MME predictions are less able to distinguish the difference at onemonth lead $(\mathrm{r}=0.85)$, although the predictions of each pattern are still well-correlated with observation $(\mathrm{r}=0.95$, $\mathrm{r}=0.81$; see Fig. $5 \mathrm{c}$, d). At four-month lead prediction, the ability to distinctly distinguish the two patterns is further diminished $(r=0.87)$, despite the MME being able to predict the indices of canonical El Niño and El Niño Modoki (See Fig. 4, hindcast correlations for Niño3 and EMI are 0.91 and 0.80 , respectively). This conundrum arises because of systematic model error in the representation of the canonical El Niño mode, which shifts westward and becomes overly dominant with increasing lead time. Despite the limitation, hindcast skills are, in general, significant and high for regions of the tropical Eastern

(a) El Nino (observation)

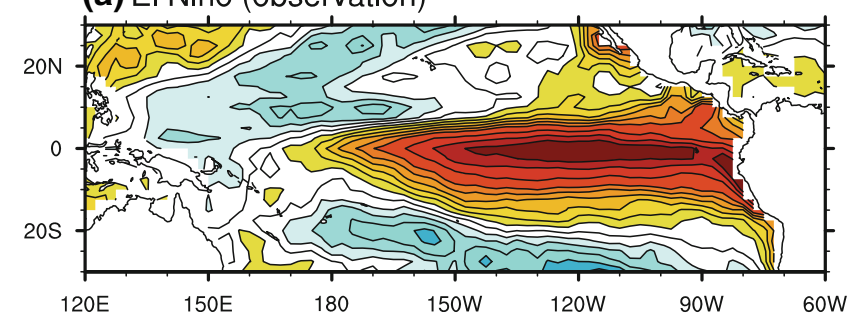

(c) El Nino (MME) at $1 \mathrm{M}$ lead

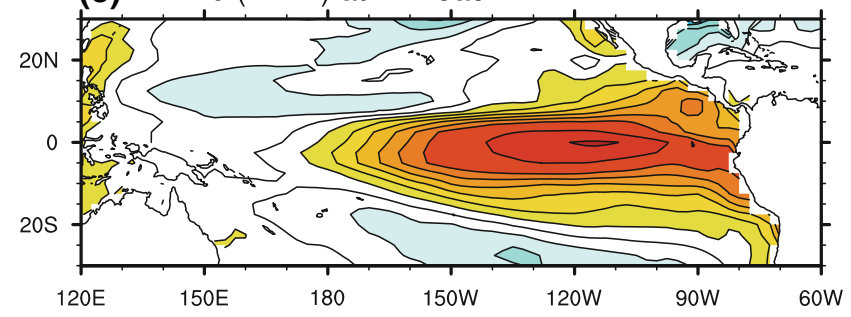

(e) El Nino (MME) at $4 \mathrm{M}$ lead
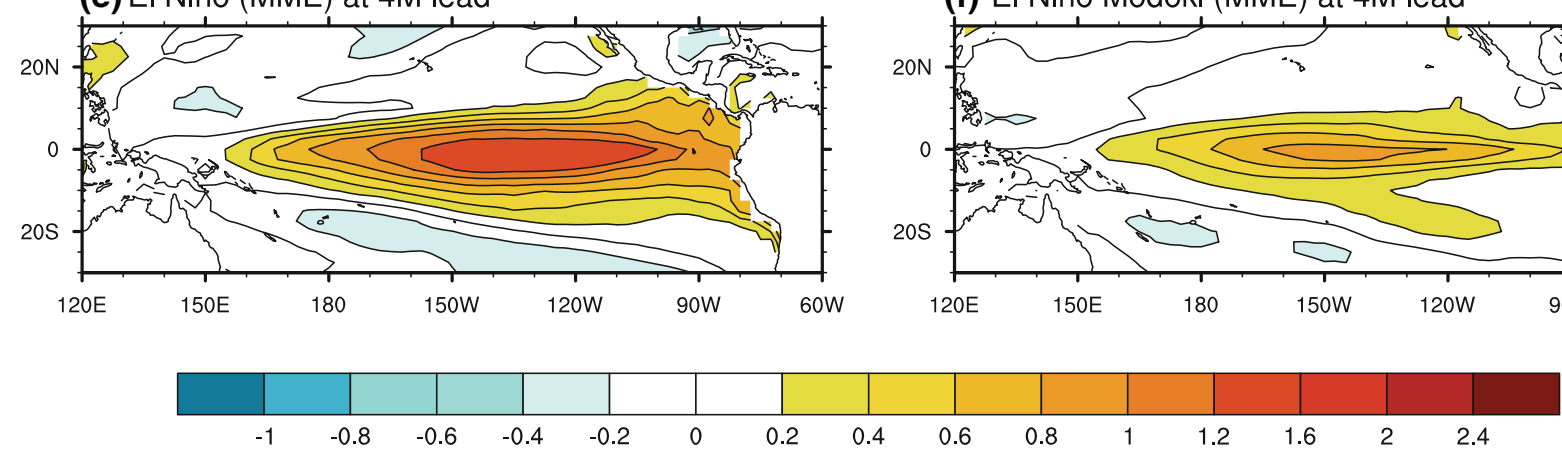

Fig. 5 SST composites of El Niño events (1982-1983, 1987-1988 and 1997-1998) and El Niño Modoki events (1994-1995, 2002-2003 and 2004-2005) during boreal winter season for observation (upper),
Pacific where the impacts from both the phenomena are very different during DJF (Ashok et al. 2007; Weng et al. 2009; Yeh et al. 2009).

\section{Regional climate impacts}

As shown in the previous section, the APCC coupled MME prediction is able to capture the two types of ENSO successfully at 1- and 4-month lead. In this section, we briefly revisit the distinctive impacts of two types of ENSO around the Pacific Rim, and examine how the coupled MME performs in predicting the observed impacts.

4.1 Remote climate associated with the SST variability over the tropical Pacific

The relationships between rainfall variability and circulation with two leading EOFs of tropical Pacific SST variability are demonstrated by regressing the observed rainfall

\section{(b) El Nino Modoki (observation)}

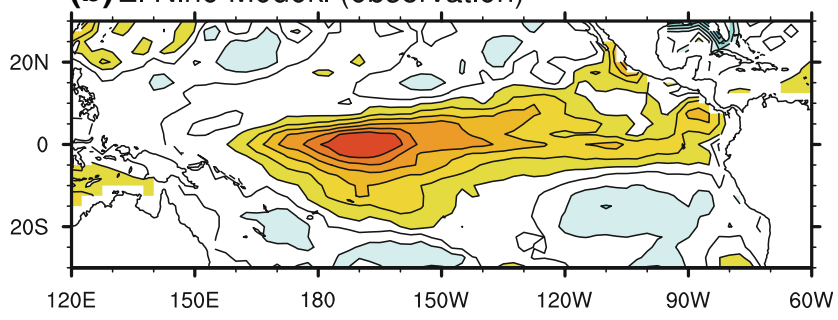

(d) El Nino Modoki (MME) at 1 M lead

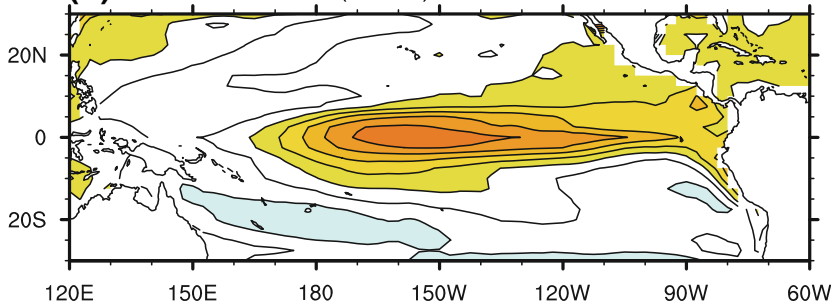

(f) El Nino Modoki (MME) at 4M lead

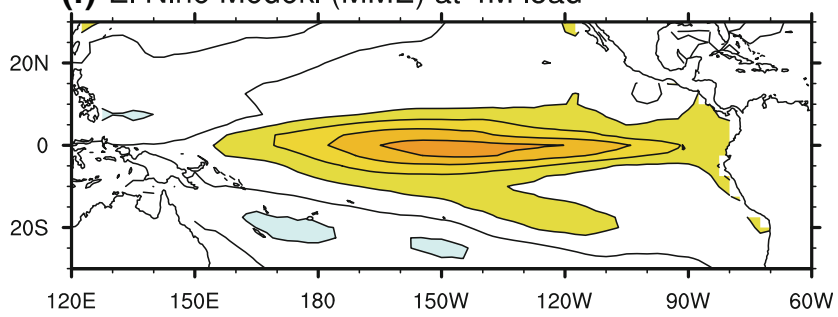

1-month lead MME predictions (middle) and 4-month lead MME predictions (lower). The left panels are for El Niño and the right ones are for El Niño Modoki 
and $850 \mathrm{hPa}$ circulation anomalies on to each of the two standardized PCs (Fig. 6a, b). During a canonical El Niño ${ }^{7}$ (Fig. 6a), there are positive rainfall anomalies over ITCZ in the eastern and central Pacific, flanked to the west by a broad horse-shoe shaped negative rainfall anomaly centered in the western tropical Pacific that extends eastward into the northern and southern Pacific. Anomalously dry conditions are seen in the SPCZ, Maritime Continent, western tropical Pacific and Philippines under the apparent influence of an anomalous low level anticyclone (in agreement with Weng et al. 2009). Below normal rainfall conditions over most of Australia are seen under influence of anomalous anticyclone. An anomalously strong winter monsoon rain band extends from the regions of eastern coastal China to the southern ocean part of Japan. The eastern North Pacific is under the influence of an anomalous cyclonic circulation $\left(150^{\circ} \mathrm{W}, 50^{\circ} \mathrm{N}\right)$. Over the tropical South America, there is an anomalously strong high pressure (Figure not shown), which induces drought conditions. These unique features are already documented in earlier studies such as Ropelewski and Halpert (1987, 1989); Diaz et al. (2001); Saji and Yamagata (2003), and Ashok et al. (2007). In contrast, during the Modoki El Niño (Fig. 6b), anomalously wet conditions occur to the west of the dateline (e.g., Larkin and Harrison 2005b; Ashok et al. 2007; Weng et al. 2009). The winter monsoon in central eastern China is anomalously weak, whereas it is strong during canonical El Niño. The anomalous rainfalls associated with the two tropical Pacific phenomena during this season are also opposite to one another in Japan. It is also noteworthy that there is an anomalously weak cyclonic circulation over the eastern parts of Brazil, apparently causing anomalously wet conditions over the region of interest. Anomalously positive rainfall is seen (Fig. 6b) in the southeastern regions of Australia associated with El Niño Modoki events as opposed to the anomalously dry conditions during canonical El Niño events (Fig. 6a). These findings agree with Weng et al. (2009).

We now assess how well the MME predicts the aforementioned rainfall and circulation features associated with two types of El Niño by carrying out a regression analysis similar to that for observations. The regression pattern of the hindcast rainfall and $850 \mathrm{hPa}$ circulation onto $\mathrm{PC} 1$ at 1-month lead time is shown in Fig. 6c. The MME prediction replicates the observed features, in general, well. For instance, the anomalously strong monsoon rainfall in East Asia, anomalously wet (dry) conditions over North

\footnotetext{
${ }_{7}$ From linear considerations associated with the regression method, we can expect that the impacts of La Niña (La Niña Modoki) are opposite to those of El Niño (El Niño Modoki). As it can be seen, the limitation stems from the fact that the non-linearity in the impacts is not addressed.
}

(tropical South) America, and less than normal rainfall in northern Australia are well represented. However, the unrealistic anomalously wet conditions to the west of the date line through the equatorial maritime continents in the predictions, which we attribute to the systematic model bias in the representation of the canonical El Niño, are endemic in all of the individual coupled models. At 4-month lead time (Fig. 6e), the regression patterns of the rainfall and atmospheric circulation are very similar to those at 1-month lead time. The monsoon band over East Asia becomes narrower and weaker, and southeastern portions of Australia now show anomalously dry condition.

The observed dipole of anomalously wet and dry rainfall anomalies over the equatorial central Pacific associated with the El Niño Modoki is well predicted retrospectively by the 1- and 4-month lead predictions (Fig. 6b, d, f). Moreover, the MME predictions at both lead times predict the anomalously weakened winter monsoon from Sumatra to the southern Japan well. However, the observed anomalously wet conditions in northern Japan are not correctly simulated. There are further limitations in predicting the atmospheric circulation and rainfall anomalies in the middle latitudes $\left(30^{\circ} \mathrm{S}-60^{\circ} \mathrm{S}\right)$ of southern hemisphere, particularly the anomalously wet conditions associated with the El Niño Modoki in the eastern region of Australia, and New Zealand.

The observed patterns of anomalous $850 \mathrm{hPa}$ temperature and $500 \mathrm{hPa}$ geopotential height associated with an El Niño comprise of warm temperature anomalies (Fig. 7a) in the eastern equatorial Pacific, Canada and northern part of USA, most of East Asia including Korea and Japan, and west and east edge of Australia; On the other hand, most of the North and South Pacific Ocean and southern North America are covered by anomalously cold temperature signals. The 1- and 4-month lead MME predictions also reasonably represent the main features such as the dipole temperature pattern over tropical Pacific, and north-south temperature and $500 \mathrm{hPa}$ geopotential height anomalies contrast over North America in El Niño years (Fig. 7c, e).

The El Niño Modoki events are associated with a tripole-like temperature anomaly pattern at the lower level in the tropical Pacific (Fig. 7b), The corresponding temperature anomalies outside the tropics are also very different from those during an El Niño, such as the anomalously warm region from northern Japan through the west coast of North America, flanked by the very cold anomalies over the northeastern North America. The MME captures (Fig. 7d, f) the west-east temperature anomaly contrast over North America associated with El Niño Modoki events at 1-month as well as 4-month lead time. However, the predicted anomalous temperature signature over the Gulf of Mexico and central and southeast Australia is unrealistic. 
(a) Regression on PC1 (observation)

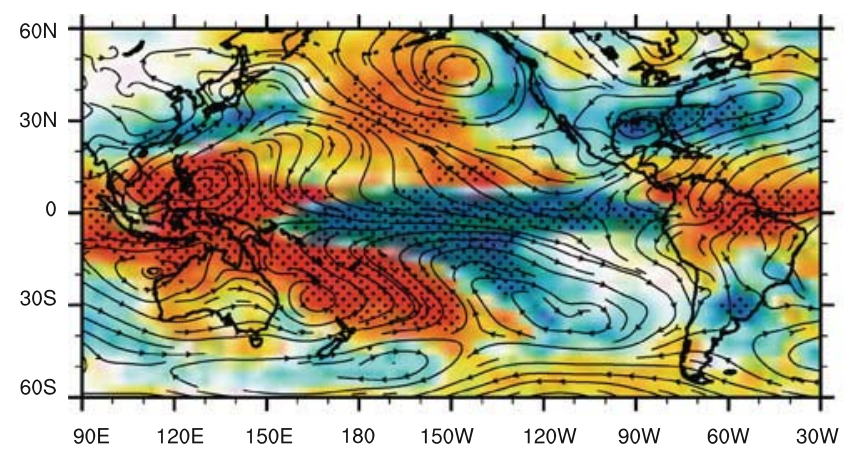

(c) Regression on PC1 (MME) at $1 \mathrm{M}$ lead

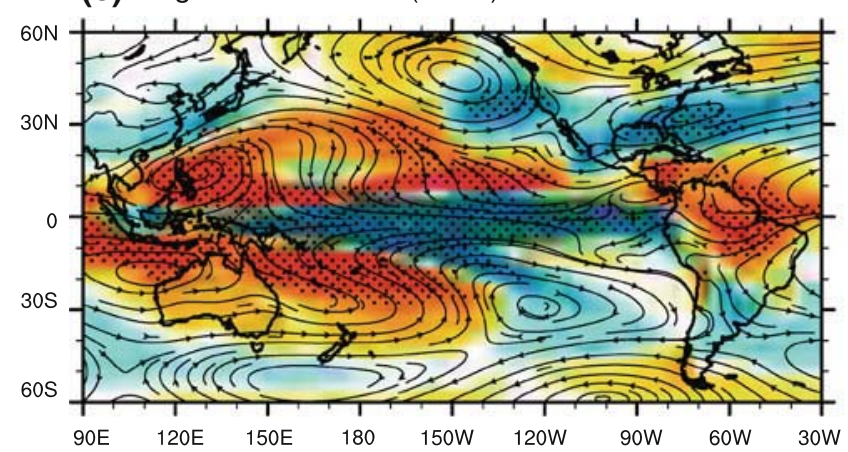

(e) Regression on PC1 (MME) at 4M lead

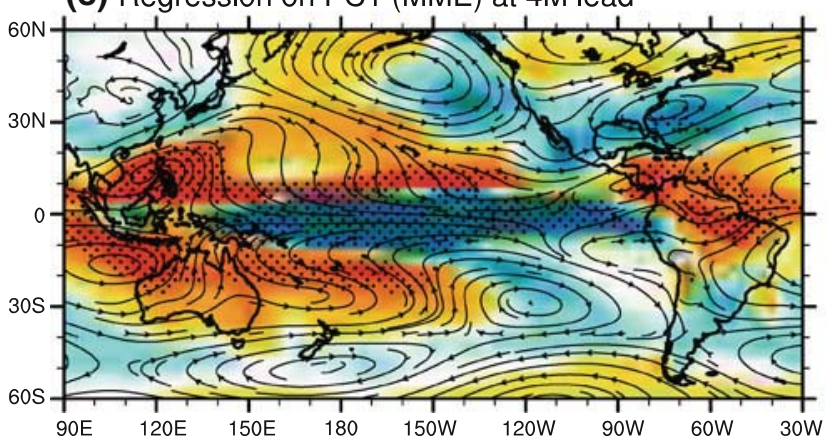

(b) Regression on PC2 (observation)

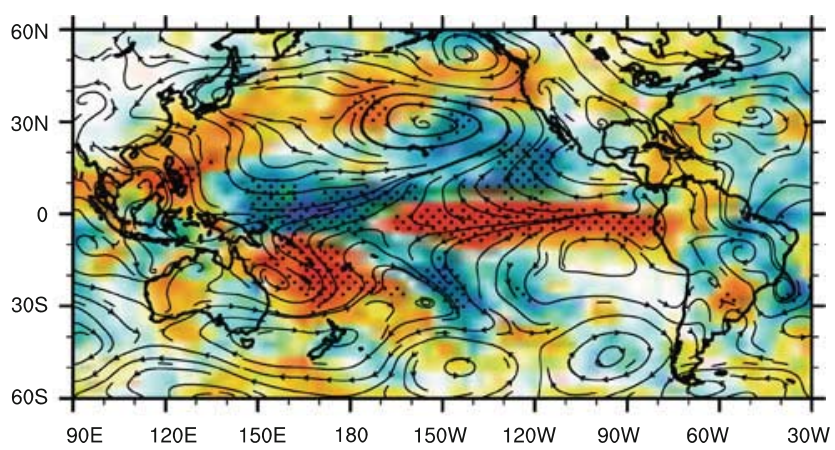

(d) Regression on PC2 (MME) at $1 \mathrm{M}$ lead

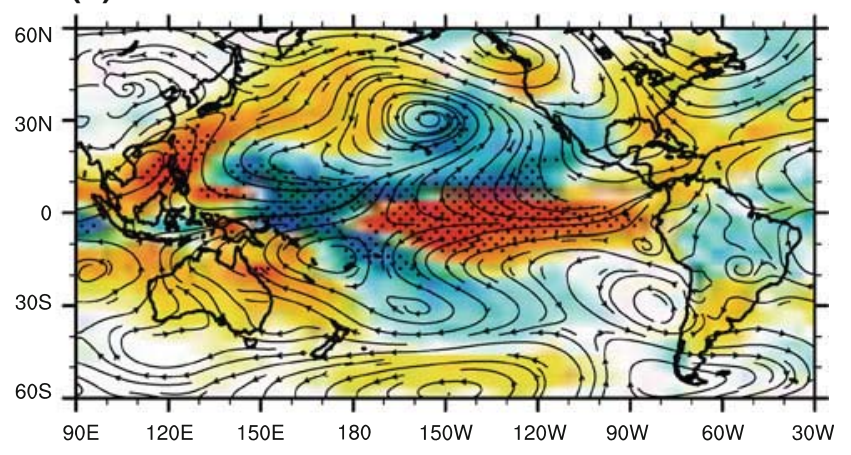

(f) Regression on PC2 (MME) at 4M lead

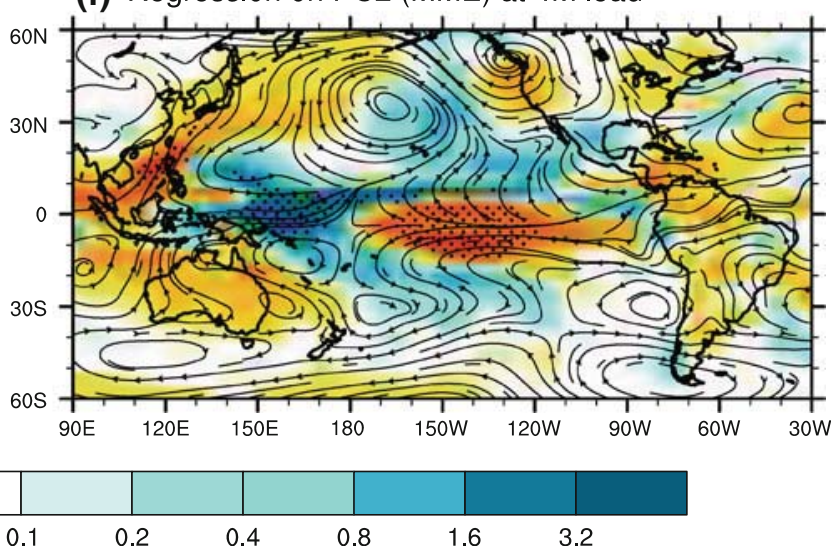

and $\mathbf{e}$ and $\mathbf{f}$ Same as $\mathbf{a}$ and $\mathbf{b}$, except for the MME prediction at 1- and 4-month lead time, respectively. The stippled areas represent significant regression coefficients at the $95 \%$ confidence level

(Fig. 8a) the pattern correlations between the observed and predicted rainfall associated with canonical and Modoki ENSO, for the four different regions surrounding tropical Pacific, namely, Australasia ${ }^{8}\left(45^{\circ} \mathrm{S}-10^{\circ} \mathrm{S}, 110^{\circ} \mathrm{E}-180^{\circ} \mathrm{E}\right)$, East Asia $\left(20^{\circ} \mathrm{N}-60^{\circ} \mathrm{N}, 90^{\circ} \mathrm{E}-150^{\circ} \mathrm{E}\right)$, North America $\left(20^{\circ} \mathrm{N}-60^{\circ} \mathrm{N}, 140^{\circ} \mathrm{W}-50^{\circ} \mathrm{W}\right)$, and tropical South America 8 Australasia is defined by a region of Oceania comprising Australia,
New Zealand, and neighboring islands in the southwest Pacific Ocean. Modoki ENSO at 1- and 4-month lead times, we present 
(a) Regression on PC1 (observation)

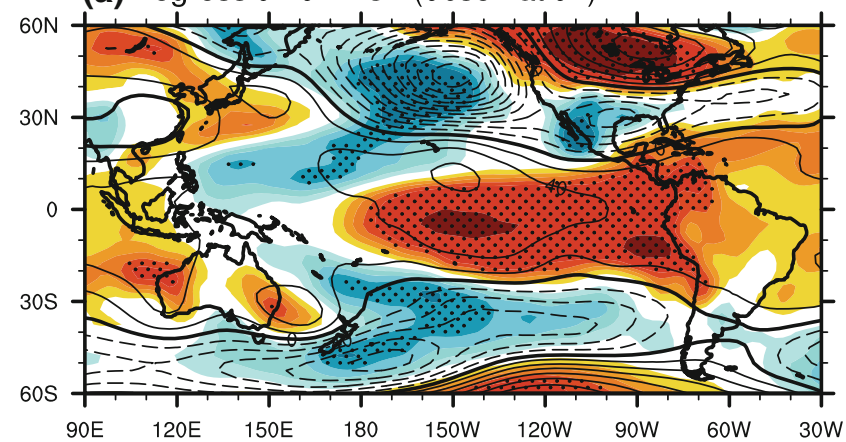

(c) Regression on PC1 (MME) at $1 \mathrm{M}$ lead

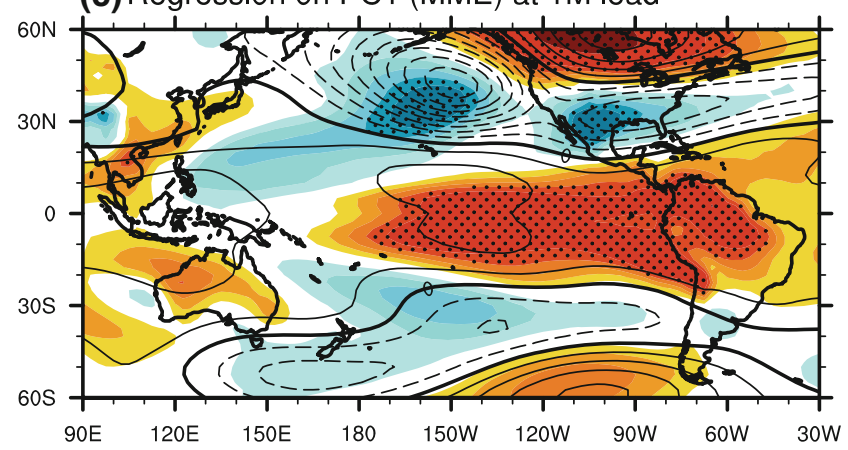

(e) Regression on PC1 (MME) at 4M lead

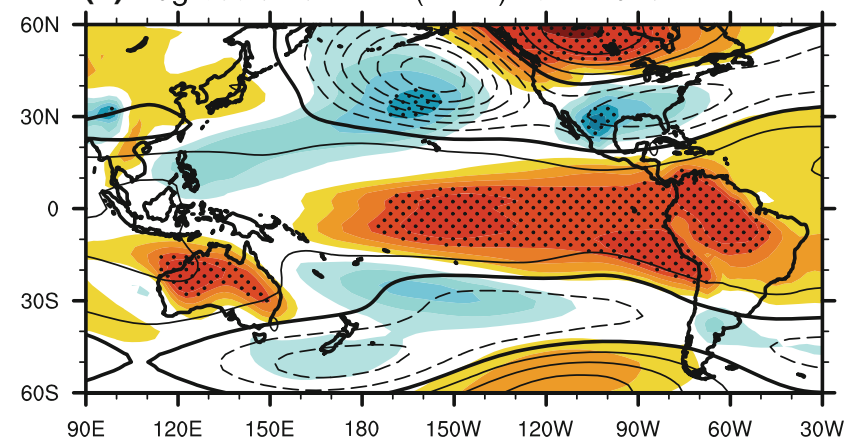

(b) Regression on PC2 (observation)

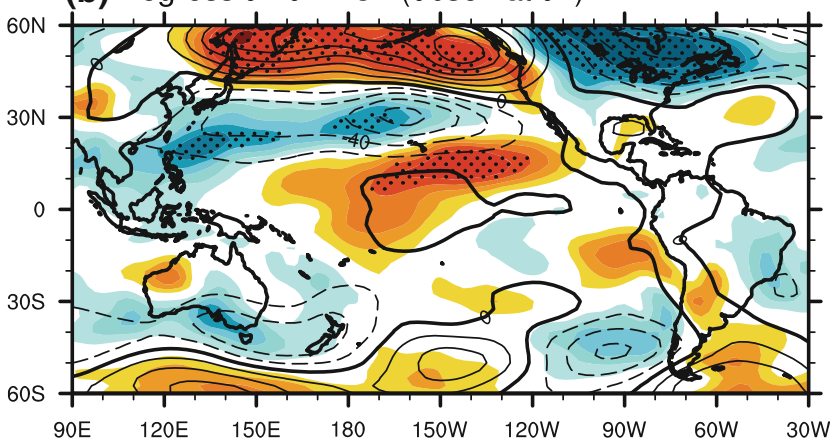

(d)Regression on PC2 (MME) at 1M lead

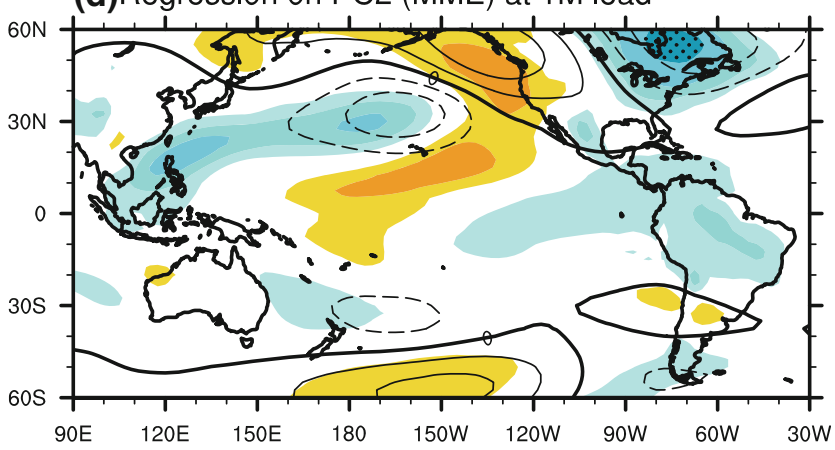

(f) Regression on PC2 (MME) at 4M lead

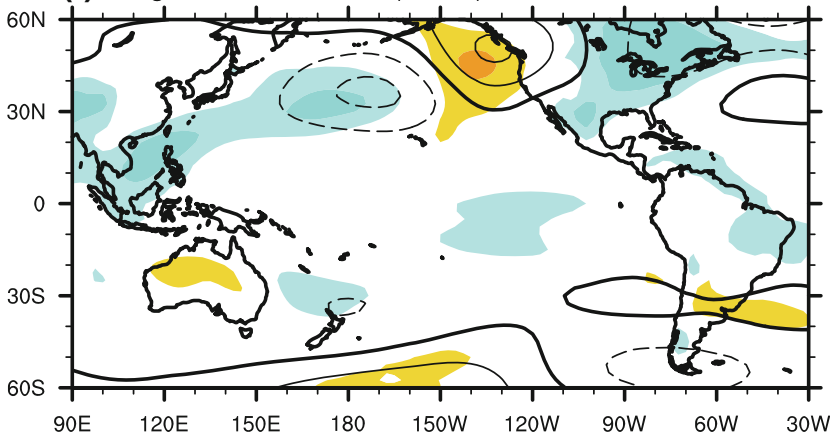

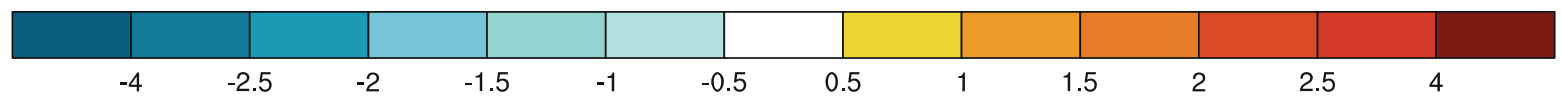

Fig. 7 Same as Fig. 6, except for the regressed patterns of temperature anomalies at $850 \mathrm{hPa}$ (shading; unit: K) and anomalous 500 hPa geopotential heights (contour; unit: $\mathrm{m}$ ). Contour interval is $20 \mathrm{~m}$

$\left(15^{\circ} \mathrm{S}-10^{\circ} \mathrm{N}, 80^{\circ} \mathrm{W}-35^{\circ} \mathrm{W}\right)$. The corresponding skills in predicting the temperature at $850 \mathrm{hPa}$ are presented in Fig. 8b. Figure $8 \mathrm{a}, \mathrm{b}$ indicate that at 1 -month lead time the predictive skills of the MME are significantly better in predicting the ENSO-associated impacts as compared to those for impacts of ENSO Modoki, except for East Asia. Specifically, the pattern correlation coefficient for rainfall associated with the canonical ENSO reaches above 0.8 (significant at $90 \%$ confidence level for two-tailed Student's $t$ test; also see Table 2) for these three regions. In contrast, for East Asia, the ENSO Modoki-associated impacts are better predicted (see Tables 2, 3) at both 1- and 4-month lead. In general, the 4-month lead MME prediction for rainfall and $850 \mathrm{hPa}$ temperature anomaly exhibits a poorer performance than 1-month lead MME predictions.

\subsection{Performance of MME versus that of the individual models}

In order to compare the performance in prediction of MME and five individual models for the teleconnection patterns which are regressed on their corresponding principal 
Fig. 8 a Pattern correlation coefficients between regressed patterns of observed and predicted rainfall based on PC1 (grey bars) and PC2 (white bars) of two leading EOF modes for observed and MME predicted sea surface

temperature anomalies at 1 - and 4-month lead time over the four regions of the Australasia $\left(45^{\circ} \mathrm{S}-10^{\circ} \mathrm{S}, 110^{\circ} \mathrm{E}-180^{\circ} \mathrm{E}\right)$, East Asia $\left(20^{\circ} \mathrm{N}-60^{\circ} \mathrm{N}, 90^{\circ} \mathrm{E}-\right.$ $\left.150^{\circ} \mathrm{E}\right)$, North America $\left(20^{\circ} \mathrm{N}-\right.$ $60^{\circ} \mathrm{N}, 140^{\circ} \mathrm{W}-50^{\circ} \mathrm{W}$ ), and tropical South America $\left(15^{\circ} \mathrm{S}-\right.$ $\left.10^{\circ} \mathrm{N}, 80^{\circ} \mathrm{W}-35^{\circ} \mathrm{W}\right)$. b Same as a, except for the temperature at $850 \mathrm{hPa}$

\section{(a) Rainfall}

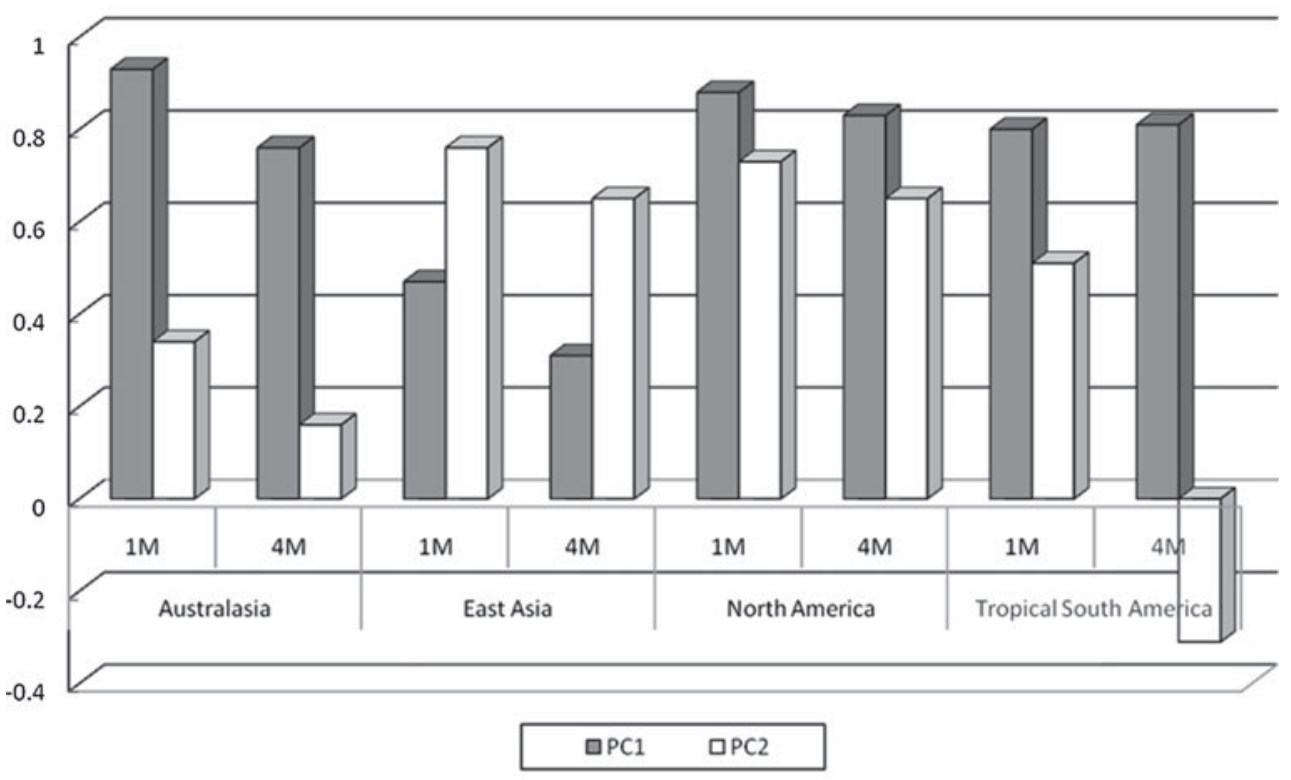

(b) Temperature at $850 \mathrm{hPa}$

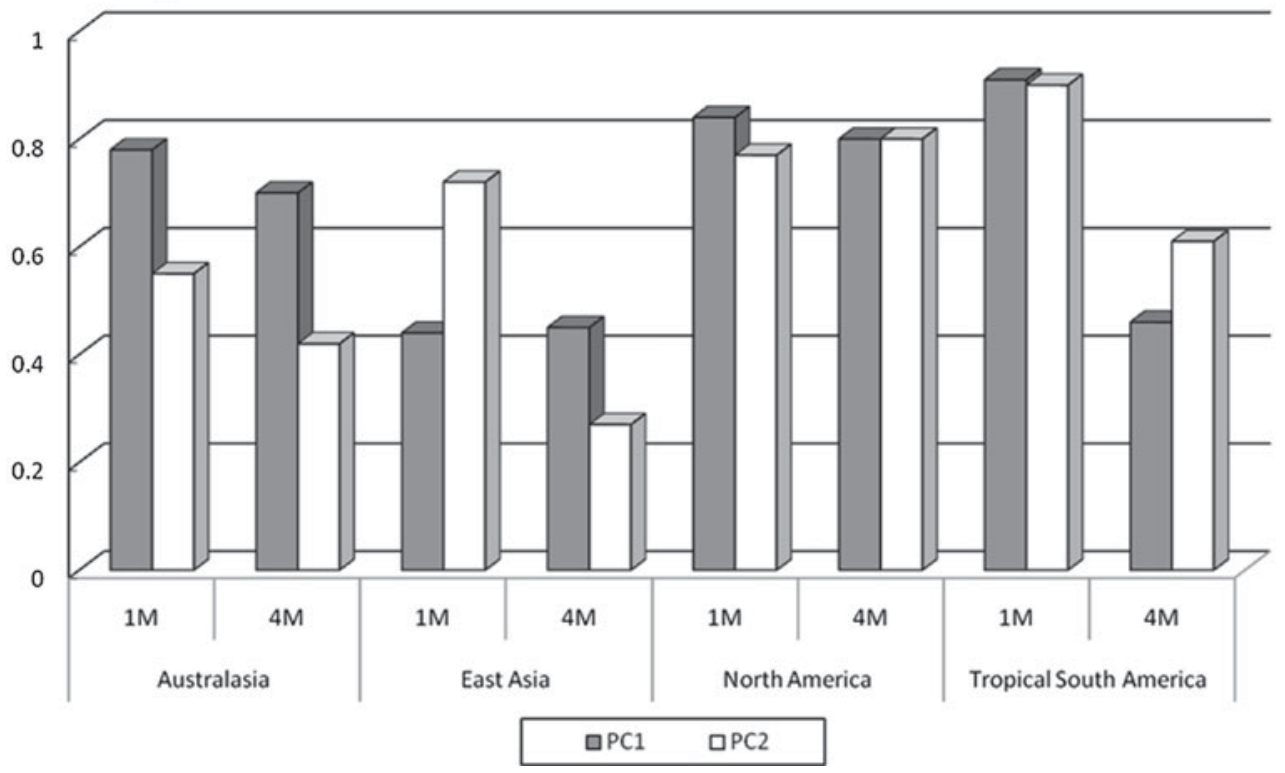

components, we have investigated the prediction skills of MME and five individual models for regional impact for the regressed rainfall and temperature at $850 \mathrm{hPa}$ based on the first two leading EOF modes of the observed and predicted SSTA at 1- and 4-month lead time over the abovementioned four different regions in Fig. 9. The mean of the prediction skills of individual models also are calculated. From the pattern correlations of the regressed rainfall on PC1 (PC2) of SST anomalies related to ENSO (ENSO Modoki) over the regions of Australasia, North America and Tropical South America (East Asia, Tropical South America) at 1-month lead, and those on PC1 (PC2) over the
North America and Tropical South America (North America) at 4-month lead, in general, we can find that the prediction performances of MMEs are better than those of the individual models.

\subsection{Limitations of the MME and possible sources of forecast error}

The velocity potential distribution at $200 \mathrm{hPa}$ in the tropics contains information concerning the overall intensity of the circulations and reflects features of low-level convergence and divergence (Tanaka et al. 2004; Weng et al. 2007; Lee 
Table 2 Pattern correlation coefficients and confidence level between observed and predicted regressed rainfall patterns on each time series of PC1 for observation and MME prediction at 1- and 4-month lead time from Fig. 2, and those on each time series of PC2 from Fig. 2 over the four regions of Australasia $\left(45^{\circ} \mathrm{S}-10^{\circ} \mathrm{S}, 110^{\circ} \mathrm{E}-180^{\circ} \mathrm{E}\right)$, East Asia $\left(20^{\circ} \mathrm{N}-60^{\circ} \mathrm{N}, 90^{\circ} \mathrm{E}-150^{\circ} \mathrm{E}\right)$, North America $\left(20^{\circ} \mathrm{N}-60^{\circ} \mathrm{N}\right.$, $\left.140^{\circ} \mathrm{W}-50^{\circ} \mathrm{W}\right)$, and tropical South America $\left(15^{\circ} \mathrm{S}-10^{\circ} \mathrm{N}, 80^{\circ} \mathrm{W}-\right.$ $\left.35^{\circ} \mathrm{W}\right)$

\begin{tabular}{|c|c|c|c|c|c|c|c|c|}
\hline & \multicolumn{2}{|c|}{ Australasia } & \multicolumn{2}{|c|}{ East Asia } & \multicolumn{2}{|c|}{ North America } & \multicolumn{2}{|c|}{ Tropical South America } \\
\hline & $\mathrm{PC} 1$ & PC2 & $\mathrm{PC} 1$ & PC2 & $\mathrm{PC} 1$ & $\mathrm{PC} 2$ & PC1 & $\mathrm{PC} 2$ \\
\hline \multicolumn{9}{|l|}{$1 \mathrm{M}$} \\
\hline Pattern correlation & 0.93 & 0.34 & 0.47 & 0.76 & 0.88 & 0.73 & 0.8 & 0.51 \\
\hline Confidence level (\%) & 98 & 70 & 70 & 90 & 95 & 90 & 90 & 80 \\
\hline \multicolumn{9}{|l|}{$4 \mathrm{M}$} \\
\hline Pattern correlation & 0.76 & 0.16 & 0.31 & 0.65 & 0.83 & 0.65 & 0.81 & -0.31 \\
\hline Confidence level (\%) & 90 & 65 & 70 & 85 & 95 & 85 & 90 & 70 \\
\hline
\end{tabular}

Table 3 Same as Table 2, except for temperature at $850 \mathrm{hPa}$

\begin{tabular}{|c|c|c|c|c|c|c|c|c|}
\hline & \multicolumn{2}{|c|}{ Australasia } & \multicolumn{2}{|c|}{ East Asia } & \multicolumn{2}{|c|}{ North America } & \multicolumn{2}{|c|}{ Tropical South America } \\
\hline & $\mathrm{PC} 1$ & PC2 & $\mathrm{PC} 1$ & PC2 & $\mathrm{PC} 1$ & $\mathrm{PC} 2$ & $\mathrm{PC} 1$ & $\mathrm{PC} 2$ \\
\hline \multicolumn{9}{|l|}{$1 \mathrm{M}$} \\
\hline Pattern correlation & 0.78 & 0.55 & 0.44 & 0.72 & 0.84 & 0.77 & 0.91 & 0.9 \\
\hline Confidence level (\%) & 90 & 80 & 75 & 85 & 95 & 90 & 95 & 95 \\
\hline \multicolumn{9}{|l|}{$4 \mathrm{M}$} \\
\hline Pattern correlation & 0.7 & 0.42 & 0.45 & 0.27 & 0.8 & 0.8 & 0.46 & 0.61 \\
\hline Confidence level (\%) & 85 & 75 & 75 & 70 & 90 & 90 & 75 & 85 \\
\hline
\end{tabular}

et al. 2011a). In this context, the observed anomalous $200 \mathrm{hPa}$ velocity potential divergent wind projected on to the corresponding indices of canonical and Modoki ENSO is presented in Fig. 10a, b, respectively. Figure 10a indicates that a canonical $\mathrm{El} \mathrm{Niño} \mathrm{is} \mathrm{associated} \mathrm{with} \mathrm{an}$ anomalous divergence center is over the central and eastern equatorial tropics, while and a secondary upper level mass source is found over the southern part of North America (Fig. 10a). Anomalous convergence is seen over the whole area of the western Pacific including Philippines and Indonesia. There is also another anomalous convergence zone over the northwest Pacific, centered at $40^{\circ} \mathrm{N}$ and $160^{\circ} \mathrm{E}$. The APCC coupled MME prediction suite, while being able to simulate (Fig. 10c, e) the general features at 1- and 4-month lead times, cannot adequately capture the secondary convergence zone in the northwest Pacific. That may the reason for the relatively limited predictive skills for rainfall in this region (see Figs. 6c, e and 8a).

Associated with an El Niño Modoki, an anomalous upper level divergence zone, centered over the central tropical Pacific and covering tropical western Pacific and Australia (Fig. 10b) is seen, flanked by a zone of convergence over the eastern tropical Pacific east of $150^{\circ} \mathrm{W}$ and also covering significant portions of Americas through midlatitude. The anomalous divergence from the main mass source at central tropical Pacific converges into a prominent upper level convergence center over the East Asia and descends over the South China Sea, suppressing the local convection as suggested by Weng et al. (2009) (Figure is not shown). The 1-month lead MME prediction is not so successful in capturing the upper atmospheric circulation in a few regions such as part of the Maritime continent, the western part of Australia and adjoining Indian Ocean (Fig. 10d). The prediction at 4-month lead time has a difficulty to capture, in addition to the above features, upper level circulation over Central and South Americas. The results are in conformation with Fig. 8a that shows low skills for precipitation over Australasia and Tropical South America.

Now, we shall try to briefly examine the inter-model spread that may have contributed to the above limitations (see Figs. 11, 12). The spread for any model in relation to the contributions to the forecast errors associated with ENSO, for example, is quantified by the root mean square difference between observed and the predicted $200 \mathrm{hPa}$ velocity potential that is regressed on to the principal component of the relevant EOF of the tropical Pacific SSTA. We find that it is difficult to simulate the secondary convergence zone over the northwest Pacific in not only the regressed pattern of $\mathrm{MME}$, but also those of most of individual models based on PC1 as compared to those based on PC2 from model spreads as forecast errors at 1- and 4-month lead time. Further, the both MME and individual 
Fig. 9 Distribution of the pattern correlation coefficients between regressed patterns of observation and model simulations on each time series of the first two EOF modes for observed and predicted SSTAs at 1-month (red) and 4-month (blue) lead time over the four regions of the Australasia $\left(45^{\circ} \mathrm{S}-10^{\circ} \mathrm{S}, 110^{\circ} \mathrm{E}-180^{\circ} \mathrm{E}\right)$,

East Asia $\left(20^{\circ} \mathrm{N}-60^{\circ} \mathrm{N}, 90^{\circ} \mathrm{E}-\right.$ $\left.150^{\circ} \mathrm{E}\right)$, North America $\left(20^{\circ} \mathrm{N}-\right.$ $60^{\circ} \mathrm{N}, 140^{\circ} \mathrm{W}-50^{\circ} \mathrm{W}$ ), and tropical South America $\left(15^{\circ} \mathrm{S}-\right.$ $\left.10^{\circ} \mathrm{N}, 80^{\circ} \mathrm{W}-35^{\circ} \mathrm{W}\right)$. The left panels are for rainfall and the right panels are for $850 \mathrm{hPa}$ temperature
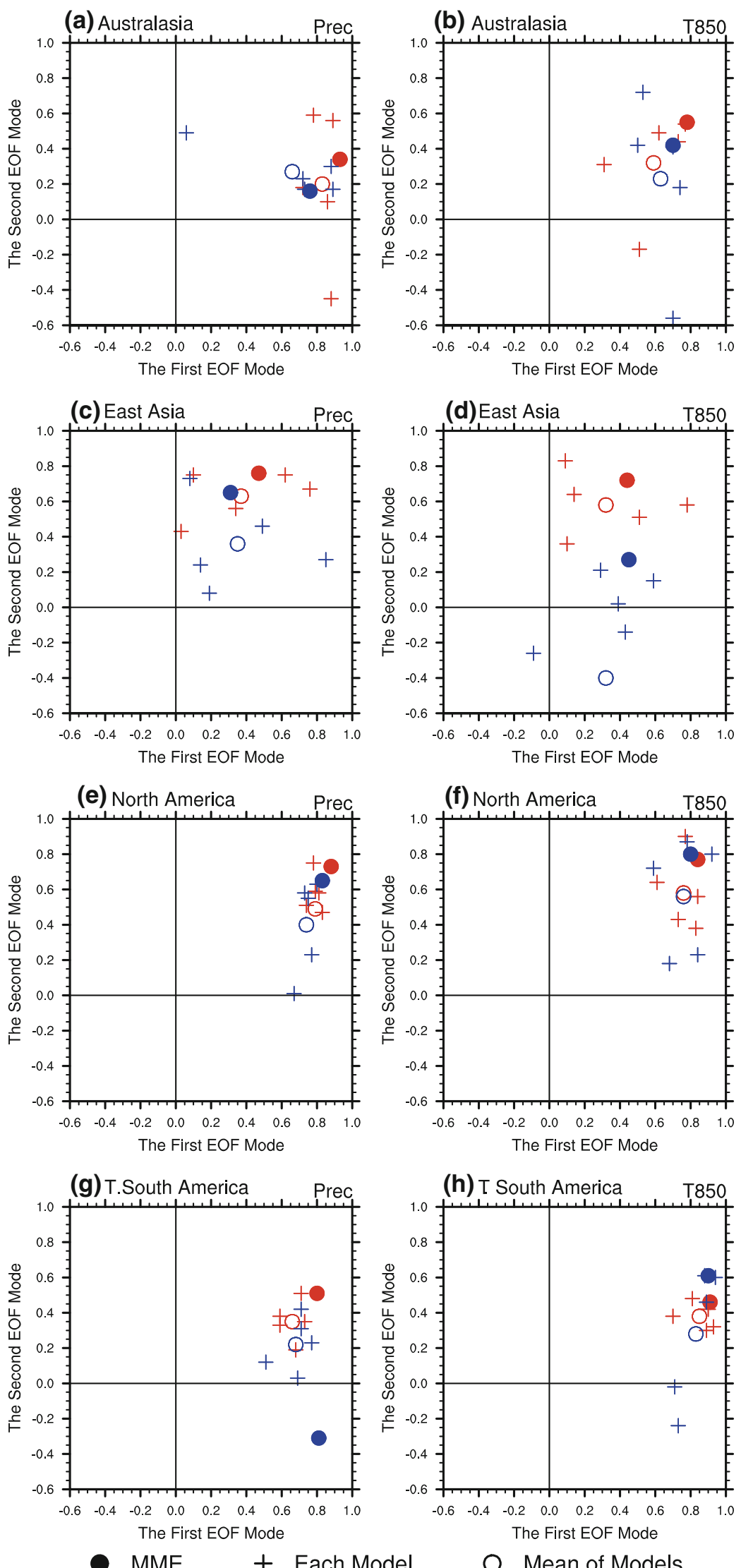

- MME + Each Model 
(a) Regression on PC1 (observation)

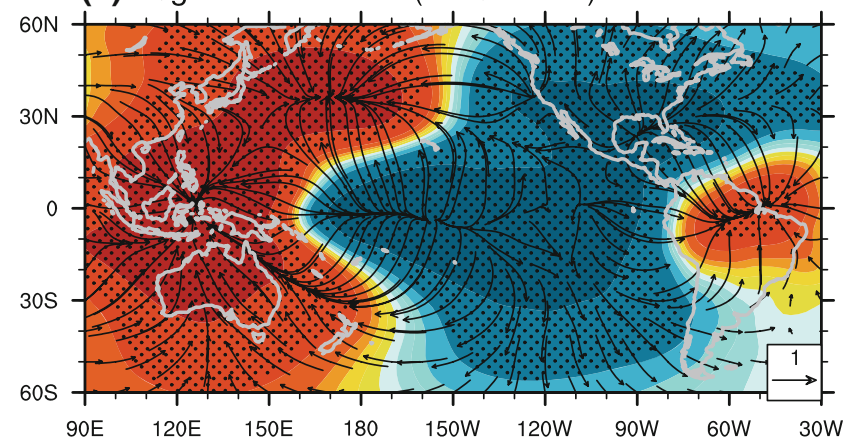

(c) Regression on PC1 (MME) at $1 \mathrm{M}$ lead

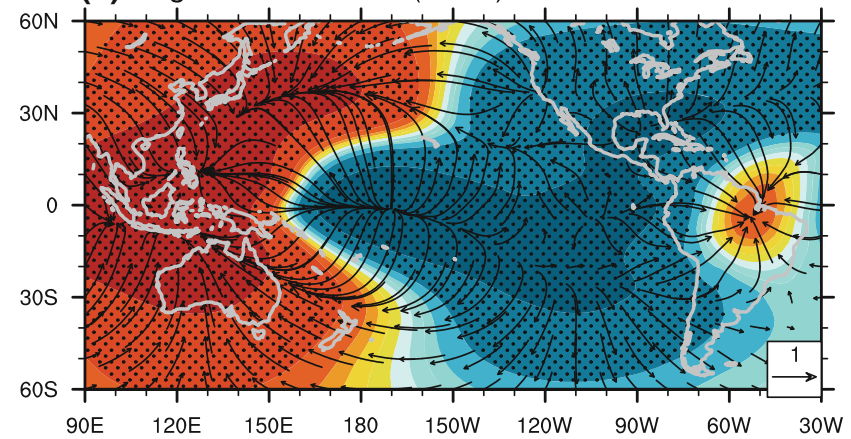

(e) Regression on PC1 (MME) at 4M lead

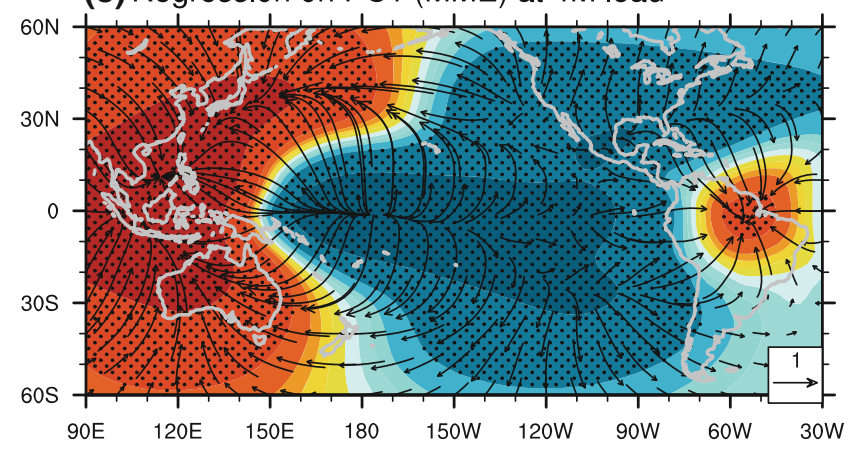

(b) Regression on PC2 (observation)

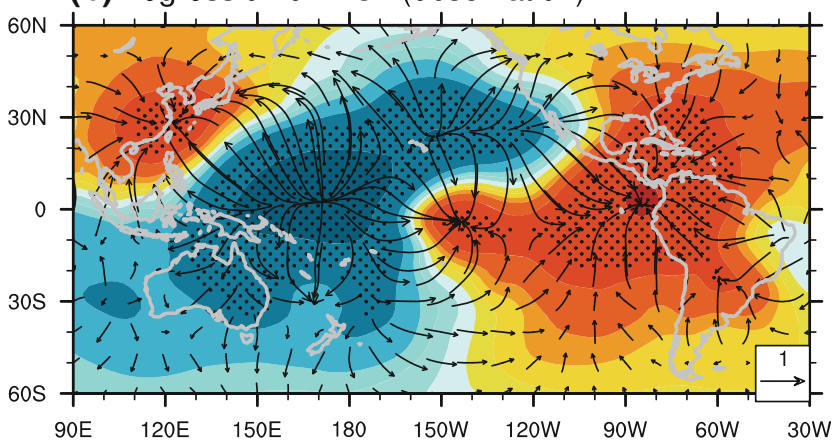

(d) Regression on PC2 (MME) at $1 \mathrm{M}$ lead

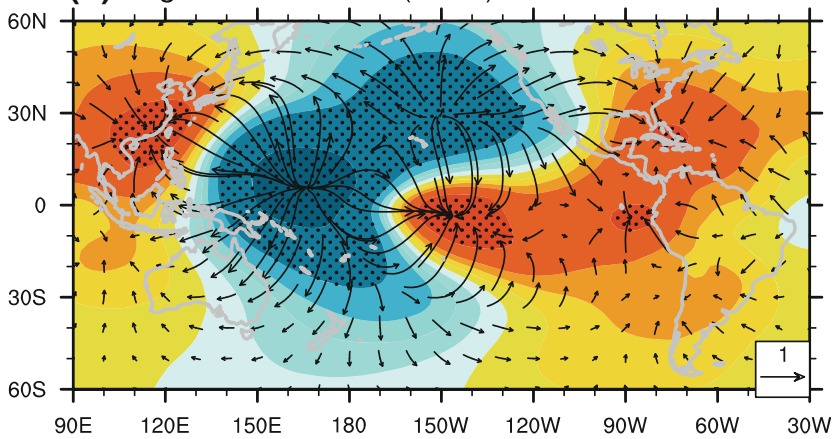

(f) Regression on PC2 (MME) at 4M lead
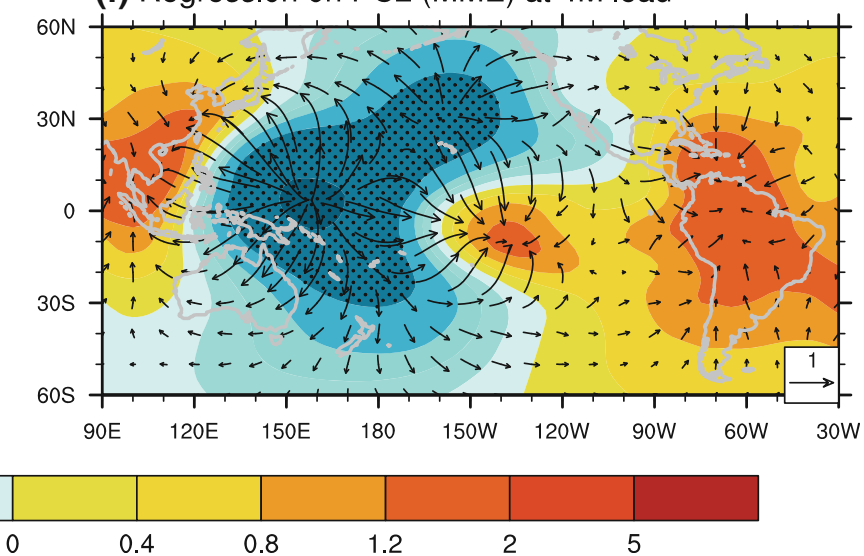

Fig. 10 Regression patterns of observed anomalous $200 \mathrm{hPa}$ divergent wind (arrow; unit: $\mathrm{ms}^{-1}$ ) and velocity potential (shading; unit: $10^{6} \mathrm{~m}^{2} \mathrm{~s}^{-1}$ ) based on a PC1 and b PC2 of two leading EOF modes for observed sea surface temperature anomalies. $\mathbf{c}$ and $\mathbf{d}$, and $\mathbf{e}$ and

model simulations associated with the ENSO Modoki indicate large model spread over part of the Maritime continent, the western part of Australia and adjoining Indian Ocean at 1-month lead time, and over Central and South America as well as the abovementioned regions at 4-month lead time. Also, these figures sufficiently indicate the relatively limitations in prediction of ENSO-associated rainfall with over the East Asia and that associated with ENSO Modoki over the Australasia at 1- and 4-month lead time; f Same as a and $\mathbf{b}$, except for the MME prediction at 1- and 4-month lead time, respectively. The stippled areas represent significant regression coefficients at the $95 \%$ confidence level

similar limitations to capture the ENSO Modoki rainfall over the tropical South America at 4-month lead is endemic to all the models (see Figs. 8a, 12).

\section{Summary and discussion}

The purpose of this work is to evaluate the ability of the APCC coupled MME suite in predicting the two types of 
Fig. 11 MME and model forecast errors associated with ENSO which are quantified by the root mean square difference between observed and predicted $200 \mathrm{hPa}$ velocity potential (unit: $10^{6} \mathrm{~m}^{2} \mathrm{~s}^{-1}$ ) regressed on to the PC1 (left panel; a-f) and PC2 (right panel; $\mathbf{g}-\mathbf{l}$ ) of the tropical Pacific SSTA at 1-month lead time (a) MME (PC1)

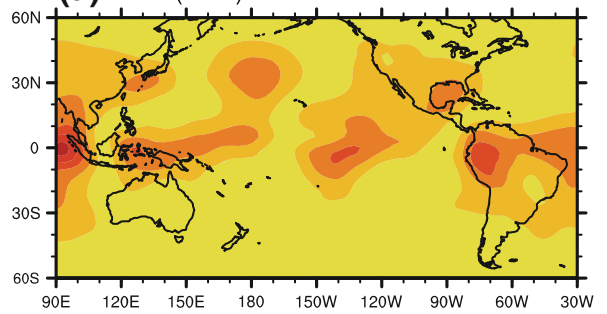

(b)Model A(PC1)

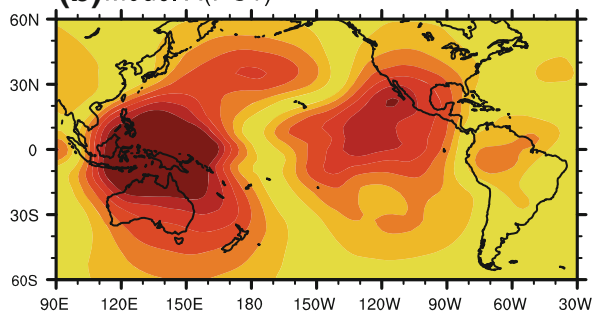

(c)Model B(PC1)

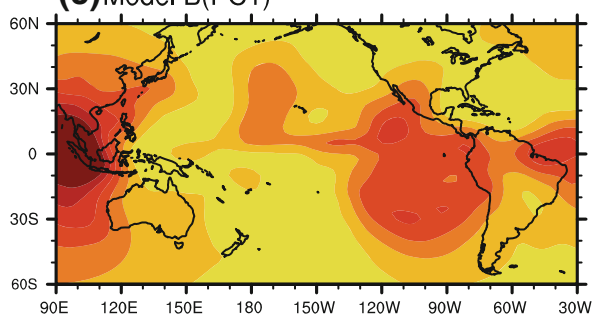

(d)Model C(PC1)

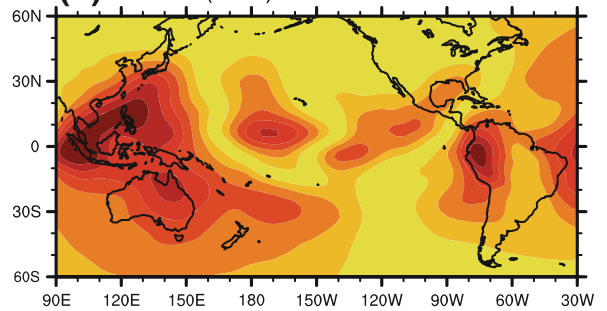

(e) Model D(PC1)

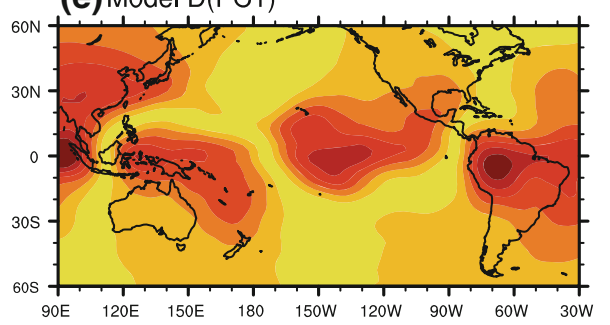

(f) Model E(PC1)

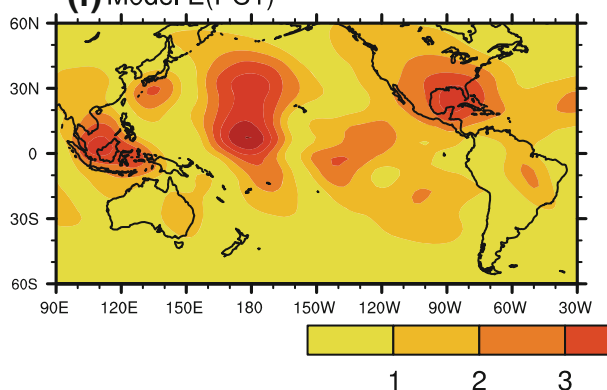

(g) MME (PC2)

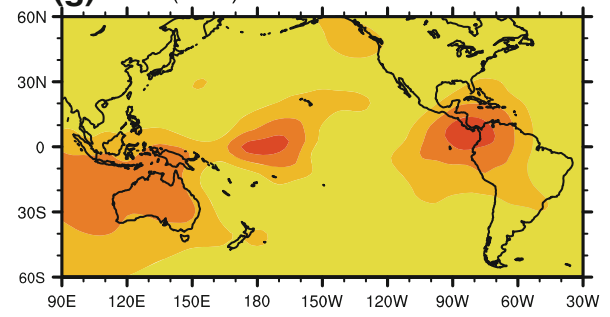

(h) Model A(PC2)

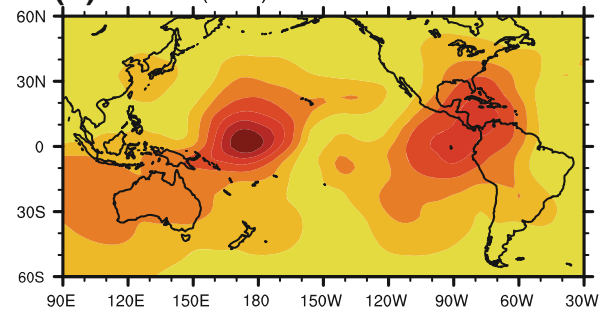

(i) Model B(PC2)

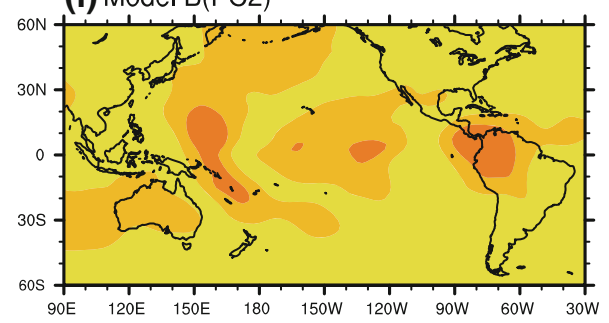

(j) Model C(PC2)

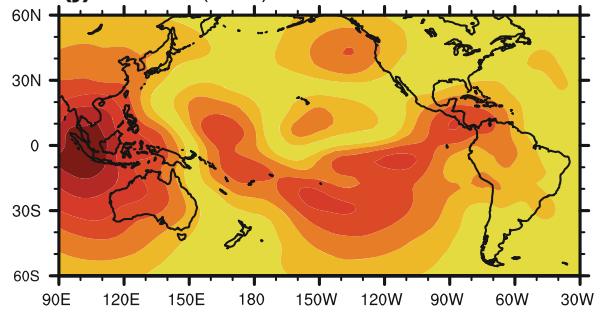

(k) Model D(PC2)

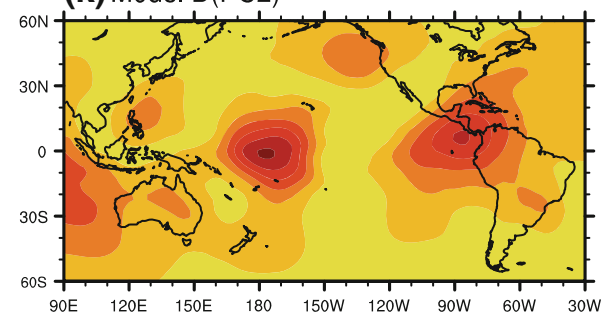

(I) Model E(PC2)

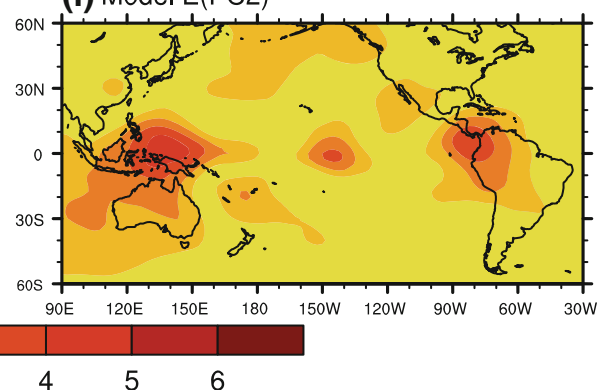


Fig. 12 Same as Fig. 11, except for 4-month lead time (a) MME (PC1)

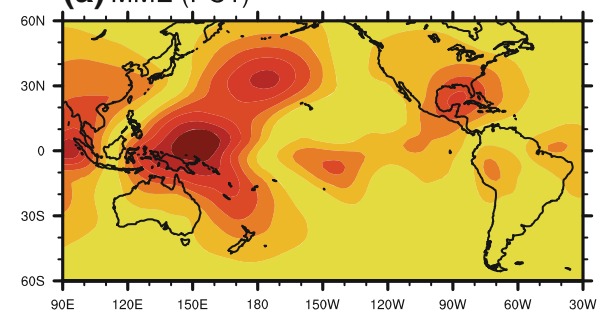

(b) Model A(PC1)

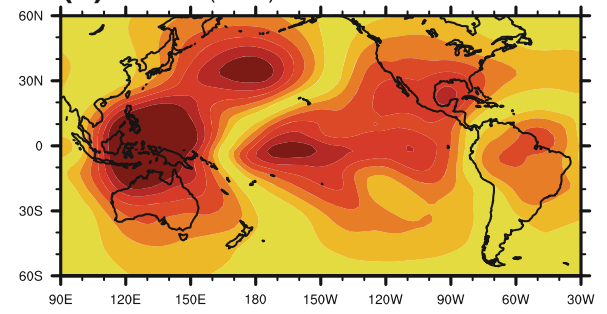

(c) Model B(PC1)

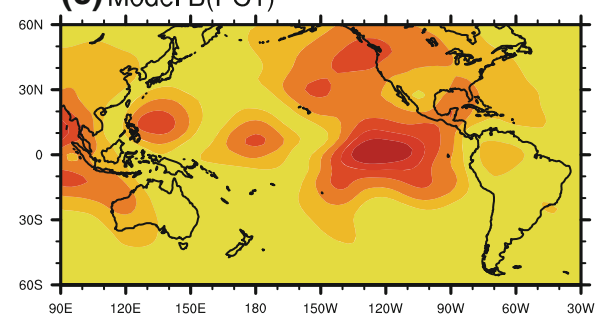

(d) Model C(PC1)

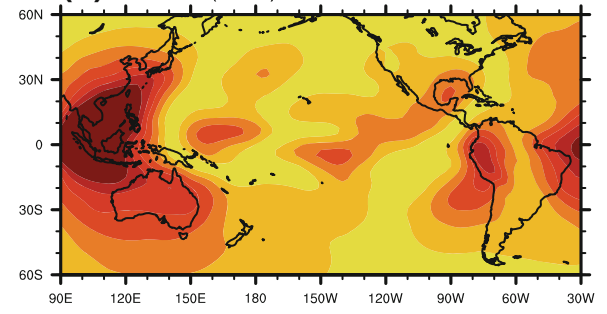

(e) Model D(PC1)

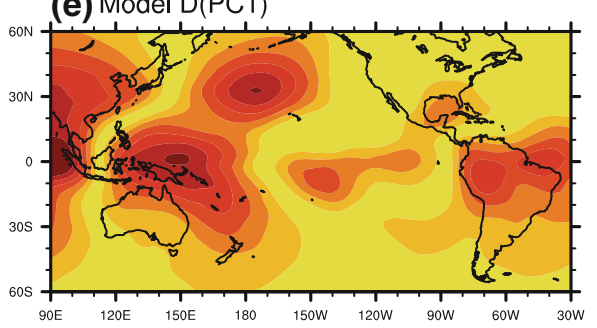

(f) Model E(PC1)

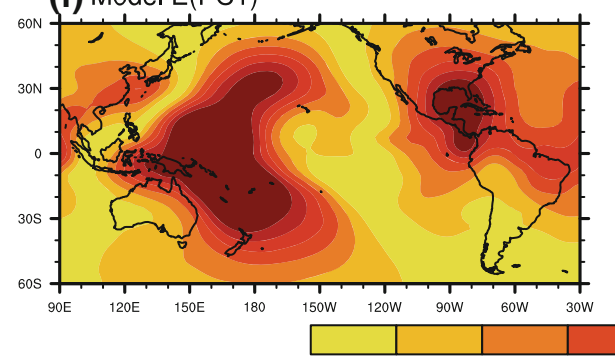

(g) MME (PC2)

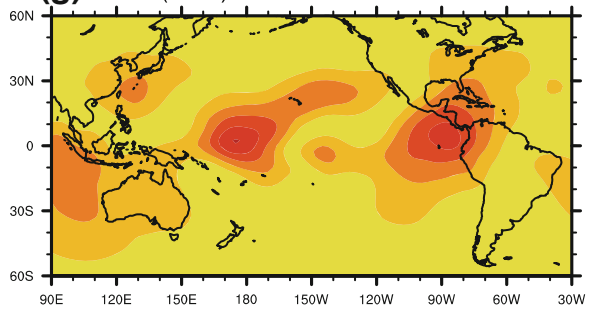

(h) Model A(PC2)

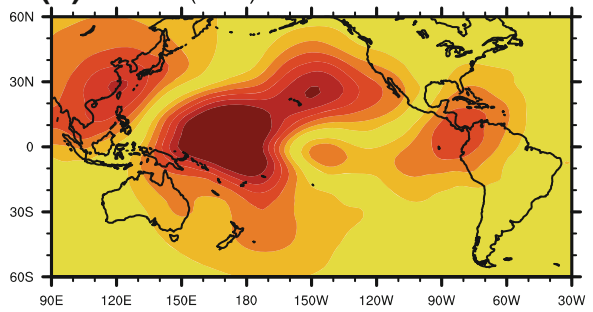

(i) Model B(PC2)

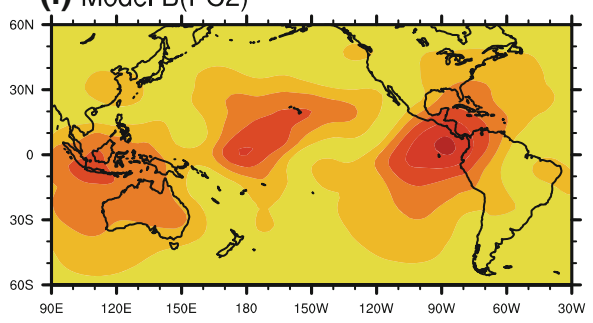

(j) Model C(PC2)

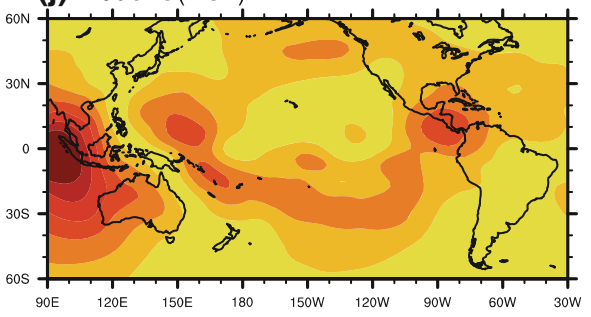

(k) Model D(PC2)

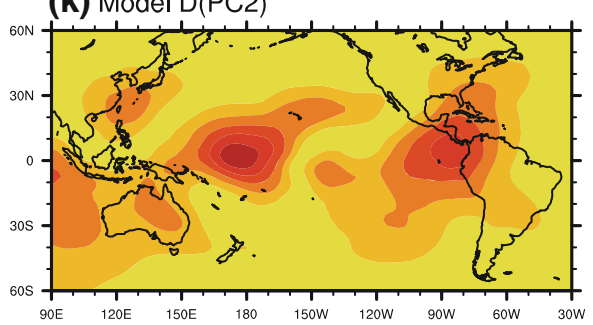

(I) Model E(PC2)

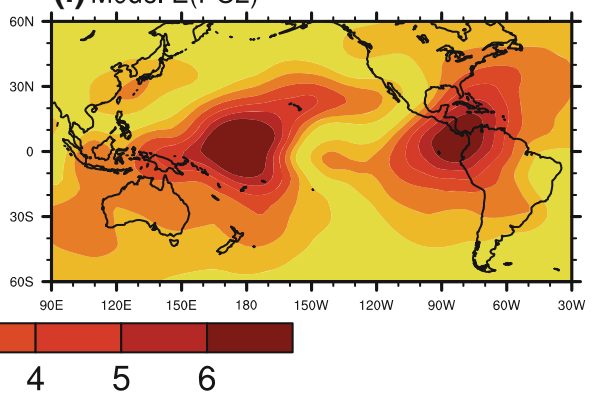


ENSO, namely cold tongue ENSO and ENSO Modoki during the boreal winter, and also to document the skills of the respective climate impacts of these Pacific climate drivers at lead time of 1-4 months, or in other words, ahead of 1 to 2 seasons.

The current work demonstrates that the APCC coupled MME prediction can simulate the ENSO and ENSO Modoki events, represented by the EOF1 and EOF2 from an EOF analysis of tropical Pacific SST anomalies, reasonably well. The spatial pattern correlations between observation and MME prediction at 1-month lead time are 0.96 for the ENSO and 0.91 for the ENSO Modoki, even though the total variance of EOF1 is much larger than that for observation, while that associated with the EOF2 is slightly under-predicted. At 4-month lead, the variance explained by the predicted EOF2 is almost less than that from observations by about $30 \%$.

When evaluating the local climate predictability over 4 specific regions, the MME prediction captures the distinguishing features such as the strong winter monsoon over East Asia, the severe drought condition and above than normal temperature over Australia, the wet and cold climate over the whole area of USA, and the anomalously dry condition over South America associated with the canonical ENSO reasonably well. However, there are limitations in predicting the ENSO Modoki-associated rainfall signatures over Australasia and tropical South America. Interestingly, the skills of the MME in predicting the ENSO Modoki-associated impacts over East Asia and North America are slightly higher or similar as compared to those related to the canonical ENSO impacts. To find out the reason, we did regression analysis of the $200 \mathrm{hPa}$ velocity potential and related divergent wind to see the upper level atmospheric circulation. In El Niño years, the MME prediction captures the observed upper level divergence (convergence) over the equatorial Pacific (East Asia and Australia) well. On the other hand, while the coupled MME prediction can simulate the El Niño Modoki-associated upper level convergence over East Asia and the divergence along the west coast of North America as well as the convergence over the eastern North America, it cannot reproduce the teleconnection paths from equatorial Pacific to Australasia and South America appropriately.

The APCC coupled MME can also predict the ENSO and ENSO Modoki indices up to 4-month lead time. Hendon et al. (2009) have also found similar prediction skills for the POAMA model for the target season of boreal autumn. Importantly, the MME skills beat the persistence for the 4-month lead. However, to finely distinguish the anomaly distribution associated with ENSO Modoki in the central tropical Pacific from that during the canonical ENSO pattern in the forecasts is an issue, and may be potential reason in limited replication of the teleconnections in parts of the Southern Hemisphere. Further development of higher resolution coupled models with improved the dynamical and physical processes, and further improvement in the data assimilation methods will hopefully improve the skills in predicting the two phenomena and their teleconnections properly within a reasonable lead time.

Though we used simple composite method to form the MME in this study, the application of a variety of the statistical MME methods (Krishnamurti et al. 2000; Yun et al. 2005; Kug et al. 2008) may also be useful in better prediction of the two phenomena. In addition, the climate filter method (Lee et al. 2011a), to separate better performing models, using the relative dynamical diagnostic performance within the model itself may contribute to further improving the seasonal prediction skills of the teleconnections from the tropical Pacific.

Acknowledgments The authors appreciate the participating institutes of the APCC coupled MME prediction system for providing the hindcast experiment data. Discussion with Prof. B. Wang is acknowledged. J.-B. Ahn was supported by the Korea Meteorological Administration Research and Development Program under Grant CATER 2012-3083. K. Ashok acknowledges the support of Prof. B. N. Goswami, Director, IITM (fully funded by MoES, Government of India), and the MoES for the SAPRISE support under the MoESNERC grant. Views expressed herein wholly are of the authors and do not reflect the views of the organizations they are affiliated to.

\section{References}

Adler RF, Huffman GJ, Chang A, Ferraro R, Xie P, Janowiak J, Rudolf B, Schneider U, Curtis S, Bolvin D, Gruber A, Susskind J, Arkin P, Nelkin E (2003) The version-2 global precipitation climatology project (GPCP) monthly precipitation analysis (1979-present). J Hydrometeorol 4:1147-1167

Ashok K, Behera S, Rao AS, Weng HY, Yamagata T (2007) El Niño Modoki and its teleconnection. J Geophys Res 112:C11007. doi: 10.1029/2006JC003798

Ashok K, Tam CY, Lee WJ (2009a) ENSO Modoki impact on the Southern Hemisphere storm track activity during extended austral winter. Geophys Res Lett 36:L12705. doi:10.1029/2009 GL038847

Ashok K, Iizuka S, Rao SA, Saji NH, Lee WJ (2009b) Processes and boreal summer impacts of the 2004 El Niño Modoki: an AGCM study. Geophys Res Lett 36:L04703. doi:10.1029/2008GL 036313

Cai W, Cowan T (2009) La Niña Modoki impacts Australia autumn rainfall variability. Geophys Res Lett 36:L12805. doi:10.1029/ 2009GL037885

Collins WD, Bitz CM, Blackmon ML, Bonan GB, Bretherton CS, Carton JA, Chang P, Doney SC, Hack JJ, Henderson TB, Kiehl JT, Large WG, McKenna DS, Santer BD, Smith RD (2006) The community climate system model version 3 (CCSM3). J Clim 19(11):2122-2143

Diaz HF, Hoerling MP, Eischeid JK (2001) ENSO variability, teleconnections and climate change. Int J Climatol 21:18451862

Donguy JR, Dessier A (1983) El Nino-like events observed in the tropical Pacific. Mon Weather Rev 111:2136-2139 
Fu C, Diaz H, Fletcher J (1986) Characteristics of the response of sea surface temperature in the central Pacific associated with warm episodes of the Southern Oscillation. Mon Weather Rev 114:1716-1739

Ham YG, Kang IS (2010) Improvement of seasonal forecasts with inclusion of tropical instability waves on initial conditions. Clim Dyn. doi:10.1007/s00382-010-0743-0

Hendon HH, Lim E, Wang G, Alves O, Hudson D (2009) Prospects for predicting two flavors of El Niño. Geophys Res Lett 36:L19713. doi:10.1029/2009GL040100

Jeong HI, Ashok K, Song BG, Min YM (2008) Experimental 6-month Hindcast and forecast simulation using CCSM3. APCC 2008 Technical Report, APEC Climate Center

Jin EK, Kinter JL III, Wang B, Park CK, Kang IS, Kirtman BP, Kug JS, Kumar A, Luo JJ, Schemm J, Shukla J, Yamagata T (2008) Current status of ENSO prediction skill in coupled O-A models. Clim Dyn 31:647-664. doi:10.1007/s00382-008-0397-3

Kanamitsu M, Kumar A, Juang HMH, Wang W, Yang F, Schemm J, Hong SY, Peng P, Chen W, Ji M (2002) NCEP dynamical seasonal forecast system 2000. Bull Am Meteorol Soc 83:10191037

Kao HY, Yu JY (2009) Contrasting eastern-Pacific and central-Pacific types of ENSO. J Clim 22:615-632. doi:10.1175/2008JCLI 2309.1

Kiehl JT, Shields CA, Hack JJ, Collins WD (2006) The climate sensitivity of the community climate system model version 3 (CCSM3). J Clim 19:2584-2596

Krishnamurti TN, Kishtawal CM, Shin DW, Williford CE (2000) Multi-model superensemble forecasts for weather and seasonal climate. J Clim 13:4196-4216. doi:10.1175/1520-0442(2000) 013<4196:MEFFWA>2.0.CO;2

Kug JS, Lee JY, Kang IS (2008) Systematic error correction of dynamical seasonal prediction using a stepwise pattern projection method. Mon Weather Rev 136:3501-3512. doi:10.1175/ 2008MWR2272.1

Kug JS, Jin FF, An SI (2009) Two types of El Niño events: cold tongue El Niño and warm pool El Niño. J Clim 22:1499-1515

Kug JS, Ahn MS, Sung MK, Yeh SW, Min HS, Kim YH (2010) Statistical relationship between two types of El Niño events and climate variation over the Korean Peninsula. Asia Pac J Atmos Sci 46:467-474. doi:10.1007/s13143-010-0027-y

Larkin NK, Harrison DE (2005a) On the definition of El Nino and associated seasonal average U.S. weather anomalies. Geophys Res Lett 32:L13705. doi:10.1029/2005GL022738

Larkin NK, Harrison DE (2005b) Global seasonal temperature and precipitation anomalies during El Nino autumn and winter. Geophys Res Lett 32:L16705. doi:10.1029/2005GL022860

Lee JY, Wang B, Kang IS, Shukla J, Kumar A, Kug JS, Schemm J, Luo JJ, Yamagata T, Fu X (2010) How are seasonal prediction skills related to models' performance on mean state and annual cycle? Clim Dyn 35:267-283. doi:10.1007/s00382-010-0857-4

Lee DY, Ashok K, Ahn JB (2011a) Toward enhancement of prediction skills of multimodel ensemble seasonal prediction: a climate filter concept. J Geophys Res 116:D06116. doi:10.1029/ 2010JD014610

Lee JY, Wang B, Ding Q, Ha KJ, Ahn JB, Kumar A, Stern B, Alves O (2011b) How predictable is the northern hemisphere summer upper-tropospheric circulation? Clim Dyn 37:1189-1203. doi: 10.1007/s00382-010-0909-9

Lim EP, Hendon HH, Hudson D, Wang G, Alves O (2009) Dynamical forecast of inter-El Niño variations of tropical SST and Australian spring rainfall. Mon Weather Rev 137:3796-3810. doi:10.1175/2009MWR2904.1

Luo JJ, Masson S, Behera S, Shingu S, Yamagata T (2005) Seasonal climate predictability in a coupled OAGCM using a different approach for ensemble forecasts. J Clim 18:4474-4497
McPhaden MJ (1999) Genesis and evolution of the 1997-1998 El Niño. Science 283:950-954

Meehl GA, Arblaster JM, Lawrence DM, Seth A, Schneider EK, Kirtman BP, Min D (2006) Monsoon regimes in the CCSM3. J Clim 19:2482-2495

Mo KC (2010) Interdecadal modulation of the impact of ENSO on precipitation and temperature over the United States. J Clim 23:3639-3656. doi:10.1175/2010JCLI3553.1

Pradhan PK, Preethi B, Ashok K, Krishnan R, Sahai AK (2011) Modoki, Indian Ocean Dipole, and western North Pacific typhoons: Possible implications for extreme events. J Geophys Res 116:D18108. doi:10.1029/2011JD015666

Rasmusson EM, Carpenter TH (1982) Variation in tropical sea surface temperature and surface wind fields associated with Southern Oscillation/El Nino. Mon Wea Rev 110:354-384

Ratnam JV, Behera SK, Masumoto Y, Takahashi K, Yamagata T (2010) Pacific Ocean origin for the 2009 Indian summer monsoon failure. Geophys Res Lett 37:L07807. doi: 10.1029/2010GL042798

Reynolds RW, Rayner NA, Smith TM, Stokes DC, Wang W (2002) An improved in situ and satellite SST analysis for climate. J Clim 15:1609-1625

Ropelewski CF, Halpert MS (1987) Global and regional scale precipitation patterns associated with the El Nino/Southern Oscillation. Mon Weather Rev 115:1606-1626

Ropelewski CF, Halpert MS (1989) Precipitation patterns associated with the high index phase of the Southern Oscillation. J Clim 2:268-284

Saha S, Nadiga S, Thiaw C, Wang J, Wang W, Zhang Q, Van den Dool HM, Pan HL, Moorthi S, Behringer D, Stokes D, Penã M, Lord S, White G, Ebisuzaki W, Peng P, Xie P (2006) The NCEP climate forecast system. J Clim 19:3483-3517

Saji NH, Yamagata T (2003) Possible impacts of Indian Ocean dipole mode events on global climate. Clim Res 25:151-169

Tanaka HL, Ishizaki N, Kitoh A (2004) Trend and interannual variability of walker, monsoon and Hadley circulations defined by velocity potential in the upper troposphere. Tellus 56A:250-269

Taschetto AS, England MH (2009) El Niño Modoki impacts on Australian rainfall. J Clim 22:3167-3174. doi:10.1175/2008JC LI2589.1

Trenberth KE, Smith L (2009) Variations in the three dimensional structure of the atmospheric circulation with different flavors of El Niño. J Clim 22:2978-2991. doi:10.1175/2008JCLI2691.1

Trenberth KE, Stepaniak DP (2001) Indices of El Nino evolution. J Clim 14:1697-1701

Turner, AG, Inness PM, Slingo JM (2007) The effect of doubled CO2 and model basic state biases on the monsoon-ENSO system. II: changing ENSO regimes Q J Roy Meteor Soc 133(Part A): $1159-1173$

Wang G, Hendon HH (2007) Sensitivity of Australian rainfall to inter-El Nino variations. J Clim 20:4211-4226

Wang B, Lee JY, Kang IS, Shukla J, Kug JS, Kumar A, Schemm J, Luo JJ, Yamagata T, Park CK (2008) How accurately do coupled climate models predict the leading modes of Asian-Australian monsoon interannual variability? Clim Dyn 30:605-619

Wang B, Lee JY, Kang IS, Shukla J, Park CK, Kumar A, Schemm J, Cocke S, Kug JS, Luo JJ, Zhou T, Wang B, Fu X, Yun WT, Alves O, Jin EK, Kinter J, Kirtman B, Krishnamurti T, Lau NC, Lau W, Liu P, Pegion P, Rosati T, Schubert S, Stern W, Suarez M, Yamagata T (2009) Advance and prospectus of seasonal prediction: assessment of the APCC/CliPAS 14-model ensemble retrospective seasonal prediction (1980-2004). Clim Dyn 33:93-117

Weng H, Ashok K, Behera SK, Rao SA, Yamagata T (2007) Impacts of recent El Nino Modoki on dry/wet conditions in the Pacific rim during boreal summer. Clim Dyn 29:113-129 
Weng H, Behera SK, Yamagata T (2009) Anomalous winter climate conditions in the Pacific rim during recent El Niño Modoki and El Niño events. Clim Dyn 32:663-674. doi:10.1007/s00382008-0394-6

Yeh SW, Kug JS, Dewitte B, Kwon MH, Kirtman BP, Jin FF (2009) El Nino in a changing climate. Nature 461:511-514. doi: 10.1038 /nature08316

Yu JY, Kao HK (2007) Decadal changes of ENSO persistence barrier in SST and ocean heat content indices: 1958-2001. J Geophys Res 112:D13106. doi:10.1029/2006JD007654
Yu JY, Kim ST (2010) Three evolution patterns of Central-Pacific El Niño. Geophys Res Lett 37:L08706. doi:10.1029/2010GL 042810

Yun WT, Stefanova L, Mitra AK, Kumar T, Dewar W, Krishnamurti TN (2005) A multi-model superensemble algorithm for seasonal climate prediction using DEMETER forecasts. Tellus Ser A $57: 280-289$

Zhao M, Hendon HH (2009) Representation and prediction for the Indian Ocean dipole in the POAMA seasonal forecast model. Q J Roy Meteorol Soc 135:337-352 